\title{
Morphological underspecification meets oblique case: Syntactic and processing effects in German ${ }^{\text {th }}$
}

\author{
Josef Bayer*, Markus Bader and Michael Meng \\ Universität Konstanz, Fachbereich Sprachwissenschaft, D-78464 Konstanz, Germany
}

\begin{abstract}
In German, oblique Cases (dative and genitive) require morphological licensing while structural Cases (nominative and accusative) do not. This difference can be captured by assuming that in German, NPs bearing oblique Case have an extra structural layer Kase phrase (KP) which is missing in NPs bearing structural Case. Focusing on dative NPs, we will show that the postulation of such a phrase-structural difference between oblique and structural case allows for a unified explanation of a wide array of facts both from the domain of grammar and from the domain of language comprehension. First, with regard to grammar, several asymmetries between dative NPs and nominative/accusative NPs follow if the former but not the latter are included within a KP-shell, including asymmetries with respect to function changing operations, clausal licensing, binding and topic drop, among others. Corroborating evidence for our analysis of dative Case in German will be provided by a comparison with data from English and Dutch. Second, when combined with certain independent assumptions about the human sentence parsing mechanism, the postulation of a KP for datives helps explain several recent experimental findings with respect to on-line sentence understanding, including the facts that dative case is dispreferred in situations of local syntactic ambiguity and that dative case may erroneously override structural case during sentence comprehension but not vice versa.
\end{abstract}

* The work underlying this article has been supported by a grant by the Deutsche Forschungsgesellschaft (Ba-1 178/4-1) to the first and second investigator and to Jens-Max Hopf. Part of the results were presented 1998 at a workshop of the Sonderforschungsbereich Theorie des Lexikons at the University of Cologne and at the Workshop on Morphological Case at the University of Utrecht. We wish to thank both audiences for stimulating discussion, especially Denis Bouchard, Lyn Nichols, Albert Ortmann and Dieter Wunderlich. Thanks to Peter Suchsland and Ralf Vogel for clarifying discussion, to Susanne Trissler for a number of suggestions as well as to Frans Hinskens, Henk van Riemsdijk. Maurice Vliegen and Jan-Wouter Zwart for their help with the Dutch data and László Molnárfi for his help with data from Afrikaans.

* Corresponding author. E-mail: Josef.Bayeruni-konstanz.de 
Keywords: Case; Kase phrase; Dative; Morpho-syntax; German; Germanic; Sentence processing

\section{Introduction}

German is usually taken to be a language with a relatively 'rich' system of morphological Case. With the exception of the masculine singular paradigm, however, the system is more or less deficient. Consider the paradigms of definite DPs for Mann ('man'), Frau ('woman') and Kind ('child') in table 1:

Table 1

Case paradigm for German definite NPs

\begin{tabular}{|c|c|c|c|c|c|c|}
\hline & \multicolumn{3}{|l|}{ Singular } & \multicolumn{3}{|l|}{ Plural } \\
\hline & Masc. & Fem. & Neut. & Masc. & Fem. & Neut. \\
\hline NOM & der Mann & die Frau & das Kind & die Männer & die Frauen & die Kinder \\
\hline AKK & den Mann & die Frau & das Kind & die Männer & die Frauen & die Kinder \\
\hline DAT & dem Mann(e) & der Frau & dem Kind(e) & den Männer-n & den Frauen & den Kindern \\
\hline GEN & des Mannes & der Frau & des Kindes & der Männer & der Frauen & der Kinder \\
\hline
\end{tabular}

We observe very little of nominal Case inflection and in various cases beyond, especially in the nominative/accusative distinction, Case syncretism. Proper names show only the genitive (or 'possessive') $-s$; bare plurals such as Frauen ('women') but also masculine nouns with (e)n plurals such as Mensch-en ('people'), Bauer-n ('peasants'), Dirigent-en ('conductors'), Professor-en ('professors') show complete Case syncretism. Consider the sample in table 2 :

Table 2

Case paradigm for German proper names and bare plurals

\begin{tabular}{lllllll}
\hline \multicolumn{5}{c}{ Proper name } & \multicolumn{2}{l}{ Bare plural } \\
\hline NOM/AKK/DAT & Maria & Friedrich Schiller & Frauen & Menschen & Bauern & Dirigenten \\
GEN & Maria-s & Friedrich Schiller-s & Frauen & Menschen & Bauem & Dirigenten \\
\hline
\end{tabular}

It has been noticed that the morphological poverty of an NP leads to asymmetrical effects across different syntactic contexts. While such elements can easily appear in subject, object and indirect object position, they are ruled out in contexts where genitive Case is required. (1) is ambiguous, but there is a very strong preference for taking the first NP as subject. The two remaining NPs can then be taken either as dative object followed by accusative object or accusative object followed by dative object, with no clearcut preference for either of these two word orders:

(1) Peter hat Maria Otto vorgestellt

Peter has Maria Otto introduced-to 
As the following data from Plank (1980: 296) show, however, no morphological lack of Case is tolerated at all in (post-nominal) genitival contexts. Bare nouns of the sort found in the right columns of table 2 are strictly excluded.

(2) a. *Benachteiligungen Frauen / Männer / Schotten discriminations women / men / Scots

b. Benachteiligungen von Frauen / Männern / Schotten discriminations of women / men / Scots

c. Benachteiligungen andergläubig-er Frauen / Männer / Schotten discriminations heterodox-GEN women / men / Scots

d. Benachteiligungen Andergläubig-er discriminations heterodox-GEN (ones)

(2a) improves to full grammaticality, if the nominal is dominated either by a von-PP as in (2b) or by an agreement projection as in $(2 c, d)$ in which genitive Case is overtly marked. Plank also observes that proper names ending in a dental or alveolar fricative are barred from this environment unless they are couched into a von-phrase or allow an augment:

(3) a. Bewohner Moskau-s / London-s /*Paris / *Graz / inhabitants Moscow-GEN / London-GEN / Paris / Graz / Graz-ens Graz-AUG-GEN

b. Bewohner von Moskau / London / Paris / Graz inhabitants of Moscow / London / Paris / Graz

In terms of current syntactic theorizing, this could mean that the dependent NP must be functionally licensed, and that this licensing can be achieved either by overt Case morphology or by the use of von, the latter, of course, in the spirit of so-called 'of-insertion'. While Plank attributed the constraint against a lack of morphological Case to the fact that post-nominal genitives are attributive rather than lexically governed terms, Schachtl (1989) observed that the constraint has a wider coverage. The data in (4) are from Schachtl's work.

(4) a. *Seitens Gutachter bestehen noch Zweifel
on-the part-of experts exist still doubts
b. *Die Aussage bedarf noch Beweise
the statement wants still proofs

They show that morphologically unmarked NPs are not allowed in the context of genitive assigning prepositions, verbs or adjectives. Again, these examples improve to full acceptability as soon as Case-bearing determiners or adjectives are inserted: d-er Gutachter, überzeugend-er Beweise, solch-er Gutachten.

The restrictions on genitive Case mentioned above are by now widely known. It is less often recognized that - despite the dataum in (1) - similar restrictions also 
hold for the dative. For reasons that will become clear in section 3 , we will not discuss the genitive in detail in this article and rather concentrate on the dative, the dative being the really challenging Case. As far as we can see, however, most of what we will say about the dative as an oblique Case pertains to the genitive as well. We will show that Case syncretism has little or no effect on the licensing of the subject (nominative) and direct object (accusative), but has severe effects on the licensing of the indirect object and dative objects in general. While the appearance of the German dative in double object constructions is to a large extent predictable and thus 'structural' in nature (cf. Czepluch, 1996; Wegener, 1985; Wunderlich, 1997), all datives - including the predictable ones - rely on morphological Case or compensatory means in a way that the 'structural' Cases nominative and accusative do not.

The article has two parts: In the first part (section 2), we will argue in favor of a morphosyntactic licensing mechanism that pertains to dative (and genitive) NPs but not to nominative or accusative NPs. We will argue that datives have an extra structural layer which is missing in nominatives and accusatives, and which we term Kase phrase (KP). A number of phenomena receive a natural explanation under the assumption of a KP. In the second part (section 3), we will show that the special reliance of dative objects on overt Case and - according to our theory $-\mathrm{KP}$ is responsible for certain garden-path effects in the on-line comprehension of German sentences. Various experimental results will be shown to link up naturally with our syntactic results. We will specify how a unified explanation can be achieved which accounts for both sets of data.

\section{Nominative/accusative versus dative}

In this part we will show that nominative and accusative form a natural class that excludes the dative (and certainly the genitive, too). We will do so by applying seven different tests most of which have already played a role in Vogel and Steinbach (1995), although Vogel and Steinbach suggested a different theoretical account. The tests in question concern function changing operations, the distribution of CPs, the distribution of indefinite nominals without a Case paradigm, topic drop (also referred to as 'pronoun zap'), types of binding, secondary predication, extraction from NP/DP and synthetic compounds. An account of the morphosyntactic form of dative Case in German will be given in 2.3. In 2.4. we turn to the obvious paradox that oblique Case must be morphologically expressed, while overt morphological marking may still be missing in datives (unlike in the genitive). We will show that these problems stem from a view of morphological marking that ignores its syntactic implementation. The material discussed in this section, Case-underspecified nominals, proper names and bare plurals, will play a central role in the experimental studies to be presented in section 3 .

\subsection{Function changing operations and nominalization}

As is widely known, function changing operations such as passive and nominalization affect the 'structural' Cases nominative and accusative while excluding the dative (and lexically selected genitive). Consider the data in (5) and (6): 
(5) a. Oswald hat den Präsidenten ermordet

Oswald has the president-ACC assassinated

b. Der Präsident wurde ermordet

the president-NOM was assassinated

c. die Ermordung des Präsidenten

the assassination the president-GEN

(6) a. Oswald hat dem Präsidenten gehuldigt

Oswald has the president-DAT given-homage

b. Dem Präsidenten/*der Präsident wurde gehuldigt

c. *die Huldigung des/dem Präsidenten

d. die Huldigung an / für den Präsidenten

the homage at / for the president

In (5b) the nominative subject is demoted while the accusative object promotes to the grammatical subject function. In marked contrast, datives never promote to subject function $(6 \mathrm{~b}) .{ }^{1}(5 \mathrm{c})$ shows that in deverbal nominals the accusative object shifts

1 The only potential counterexample to this could be the so-called 'bekommen/kriegen passive':

(i) Der Chirurg entfernte dem Patienten die Milz the surgeon-NOM removed the patient-DAT the spleen-ACC

(ii) Der Patient bekam / kriegte die Milz entfernt the patient-NOM got / got the spleen-ACC removed

Although the bekommen/kriegen passive maps argument structures onto each other in a systematic fashion, we fail to see why it should - at this stage of its diachronic development - be taken to be a syntactic function changing process. The verbs bekommen and kriegen are clearly contentful and semantically transparent in the sense that they require (positive or negative) affectedness of their external argument. Notice also that the bekommen/kriegen passive exhibits idiosyncracies which are absent in the familiar function changing processes. While certain verbs with a single dative object can undergo the process, others cannot:

(iii) a. Ich half dem Studenten - Der Student bekam / kriegte geholfen I helped the student-DAT - the student-NOM got / got helped

b. Alle gratulierten dem Opa - ??Der Opa bekam/kriegte von allen all congratulated the grand-dad the grad-dad got /got by all granuliert congratulated

(iv) a. Ich zürnte dem Studenten - *Der Student bekam / kriegte gezürnt I was-mad-at the student-DAT - the student-NOM got / got been-mad-at

b. Alle liefen dem Opa entgegen - *Der Opa bekam / kriegte von allen all ran the grand-dad toward - the grad-dad got /got by all entgegengelaufen run-toward

Other dative verbs which permit the bekommen/kriegen passive are beipflichten ('agree') and widersprechen ('object-to'); others which don't are ausweichen ('avoid'), dienen ('serve'), vertrauen ('trust'), unterliegen ('succunb') and certainly many more. Idiosyncracies can also be witnessed in double object constructions. While inalienably possessed datives undergo the bekommen/kriegen passive freely, others do not, as seen in $(v)$ :

(v) a. Man stahl mir mein ganzes Geld one stole me-DAT my whole money

b. *Ich bekam / kriegte mein ganzes Geld gestohlen I-NOM got / got my whole money stolen 
to genitive; nothing of this kind is possible when the corresponding verb selects dative (6c). As shown in (6d), the only option is to license the oblique object in a PP. These data suggest that the direct accusative object has a privileged status that sets it apart from the oblique Case dative.

This finding is corroborated by middle constructions where exactly the same distribution is found. As the data in (7) show, the accusative object corresponds to a non-thematic subject in the middle construction, whereas the dative in (8) is excluded from such privilege:

(7) a. Es ist leicht, diesen Wagen zu fahren it is easy this car-ACC to drive 'It is easy to drive this car'

b. Dieser Wagen fährt sich leicht this car-NOM drives REFL easily 'This car drives easily'

c. *Diesen Wagen fährt es sich leicht this car-NOM drives it REFL easily

(8) a. Es ist leicht, diesem Weg zu folgen it is easy this path-DAT to follow

b. *Dieser Weg folgt sich leicht this path-NOM follows REFL easily

c. Diesem Weg folgt es sich leicht this path-DAT follows it REFL easily

Obviously, the reflexive sich absorbs accusative Case such that the accusative object has to be licensed as a nominative; sich, however, never absorbs dative (or any other oblique) Case (cf. Steinbach, 1998, 2000 for relevant discussion).

Although there is undeniable systematicity in the appearance of datives in ditransitive clauses - cf. Czepluch (1996), Wegener (1985), Wunderlich (1997) among others - it is equally clear that datives are firmly excluded from function changing operations.

\subsection{Clausal licensing}

Let us consider next a set of data concerning the distribution of clausal arguments. Finite $d a \beta$-CPs in German have nominal features, a fact that is immediately plausible for the reason that $d a \beta$ derives from the deictic pronoun $d a s$. As has been observed by various researchers, however, the distribution of $d a \beta$-CPs - in earlier terminology 'NP-clauses' - is not at all the same as the distribution of NPs. As Stowell (1981) has argued, the proper generalization could be that such CPs have to

This is not the place to argue in depth against a morpho-syntactic relatedness of the bekommen/kriegen construction with a corresponding active construction, but we want to draw the reader's attention to the fact that there are other semantic regularities as in the buy/sell pair I sold John a car and John bought a car from me which have not been classically been suggested as syntactically related. 
be removed from Case positions. We are concemed here with a restriction that goes beyond this: As Fanselow and Felix (1987) and Vogel and Steinbach (1995) have observed among others, a CP can never be in a dative position or, if CPs are generally outside NP-positions proper, be linked to a dative position.
a. [Daß wir verreisen
wollten] hat niemanden
interessiert
NOM that we travel-away wanted has nobody
'That we wanted to travel interested nobody'
b. Wir bestritten [daß wir verreisen wollten] we denied that we travel-away wanted
c. ${ }^{*}$ Wir widersprachen $[\mathrm{da} \beta$ wir verreisen wollten] we objected that we travel-away wanted
ACC
DAT

The reason for the deviance of $(9 \mathrm{c})$ is obviously not semantic in nature, although this is not implausible given that dative often bears the theta role of a recipient or beneor maleficiary. The verb widersprechen, however, permits an inanimate object, thereby excluding a semantic account of the ill-formedness of $(9 \mathrm{c})$. lnserting a DPshell as in (10) rescues this example:

(10) Wir widersprachen [der Behauptung [daß wir verreisen wollten]] DAT we objected the claim that we travel-away wanted

Dative Case is morphologically spelled-out on the DP of which the CP is an explicatory part (if it is properly included at all). The correct generalization seems to be that CPs can replace or link to structural Case positions because they require only abstract Case, but that CPs cannot replace or link to a dative's position because the dative requires morphological Case licensing, a requirement that for obvious reasons CP itself cannot fulfill. Why is this so? Case in German is inflectional and can thus not be spelled out on a category that fails to be from the set $\{D$, $\mathrm{N}, \mathrm{A}$ \}. Assuming that morphological Case could be realized by a phrasal clitic or some Case particle, we expect that clauses can also be marked with dative Case. This expectation is indeed borne out. Consider the following Turkish data from Kornfilt (1985):
(11) Ahmet
Ayşe-yi [PRO sinema-ya git-meğ]-e
zorla-dı Achmed Ayse-ACC movie-DAT go-INF-DAT force-PAST 'Achmed forced Ayse to go to the movie'

In the agglutinative system of Turkish, the Case particle $-e$ is, of course, not inflectional. The contrast between the two languages shows us that CPs can in principle appear in the function of dative objects, but that due to a morphological limitation this is impossible in German. The important result is that the 'structural' Cases nominative and accusative can be satisfied by (nominal) CPs, but obliques cannot. The latter rely on overt morphological licensing. 


\subsection{Non-inflecting nominals}

German has a class of indefinite quantifiers which have nominal features but lack anything like a morphological Case paradigm. In fact, these elements are like particles, i.e. they cannot undergo any inflection. As Gallmann $(1996,1997)$ observes, they are Case-licensed in 'structural' contexts, i.e. in contexts where either nominative or accusative would be assigned, but never where dative would be assigned:

(12) a. Genug / nichts / allerlei / etwas / wenig ist schiefgegangen NOM enough / nothing / a lot / etwas / little has gone wrong

b. Wir haben genug / nichts / allerlei / etwas / wenig erlebt ACC we have enough / nothing / a lot / something / little experienced

c. *Feuchtigkeit schadet genug / nichts / allerlei / etwas / wenig humidity harms enough / nothing/a lot / something/little DAT

That the source of the defect in (12c) is really the lack of Case morphology is revealed by the behavior of the quantifiers wenig ('little') and viel ('much'). These quantifiers can be used as bare forms like genug, nichts etc.; in this form they appear also with mass nouns as in viel/wenig Wasser ('much/little water'), viel/wenig Unsinn ('much/little nonsense') etc. Alternatively, however, they can also be inflected. As Gallmann points out, while both their bare form and their inflected form are permitted in structural Case positions, only their inflected form is permitted where dative Case is required; this is shown in $(13 a-c)$ where the optional inflection appears in brackets:

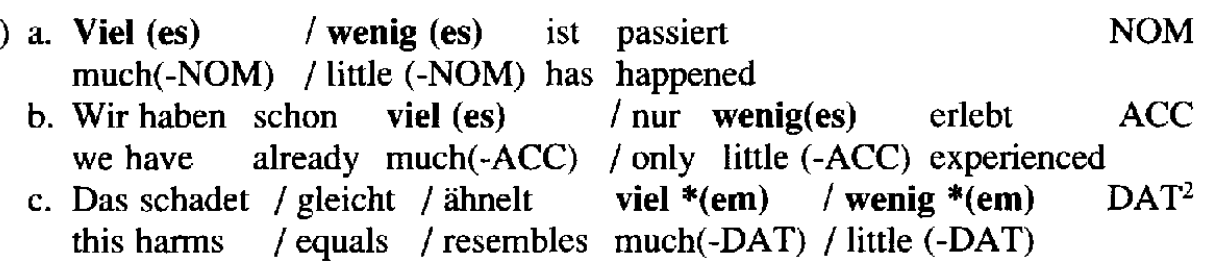

Where inflectionless forms such as viel, wenig, genug, allerlei appear with an $\mathrm{NP}$, the distribution remains the same as before. This is shown in $(14 \mathrm{a}-\mathrm{c})$ where the common noun Unsinn appears which, however, remains invariant across the three Cases in question. Lack of overt Case is tolerable in $(14 a, b)$ but not in (14c). Interestingly, things change when a Case-inflected adjective appears in the NP or is couched in a partitive von-PP, as shown in (15):

\footnotetext{
2 The form of etwas ('something') in Swiss German is öppes. Unlike etwas it has a dative form, öppisem, which must be used in the context of a dative assigning verb. Thanks to Thomas Leu for pointing this out to us.
} 
(14) a. Viel / wenig / genug / allerlei Unsinn wurde geredet NOM much / little / enough / a lot nonsense was talked

b. Otto hat viel / wenig/genug / allerlei Unsinn geredet ACC Otto has much / little / enough / a lot nonsense talked

c. *Otto hat viel / wenig / genug / allerlei Unsinn widersprochen DAT Otto has much / little / enough / a lot nonsense objected

(15) a. Otto hat viel / wenig / genug / allerlei solch-em Unsinn Otto has much / little / enough / a lot such-DAT nonsense widersprochen objected

b. Otto hat viel / wenig / genug / allerlei von dies-em Unsinn Otto has much / little / enough / a lot of this-DAT nonsense widersprochen objected

We assume that these are QPs of the form $\left[_{\mathrm{QP}} \mathrm{Q}[\mathrm{NP} / \mathrm{PP}\right.$...] ] where $\mathrm{Q}$ corresponds to the position otherwise taken by the inflecting determiner $\mathrm{D}$. We assume further that the Case feature [dat] must percolate to the uninflected head $\mathrm{Q}$ in order to license QP as a dative-marked phrase. We propose that this is possible due to the operation of feature movement ('Move-F') as proposed in Chomsky (1995: ch. 4). Consider a covert, feature-based version of N-to-D raising as proposed in Longobardi (1994) which in (15a) would operate from $A$ to $Q$ and in (15b) from $A$ to $P$ to $\mathrm{Q}$ respectively:

(16) a.

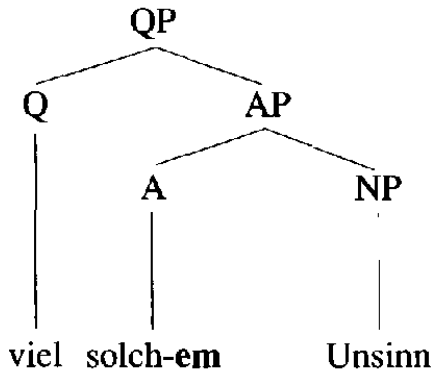

b.

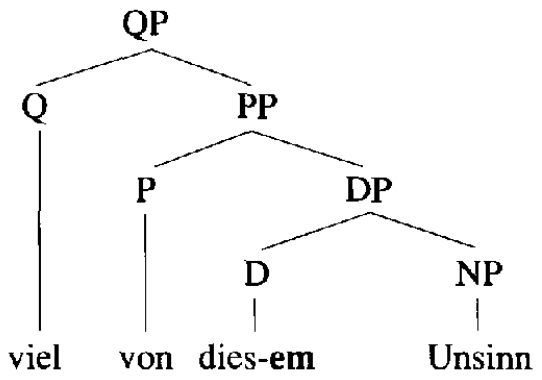

In (16a) the Case-inflected head $\mathrm{A}$ has a nominal feature that attracts the formal features of NP. We speak of FF(NP), FF(PP) etc. Since according to Chomsky (1995) $\mathrm{N}$-features are 'interpretable', they will not disappear in this operation. As must be clear from the uninflected forms in (12) and (13), Q has an $\mathrm{N}$-feature, too. This feature attracts $\mathrm{FF}(\mathrm{AP})$. But $\mathrm{AP}$ has - by virtue of $\mathrm{A}$ - not only the necessary $\mathrm{N}$-features but also the Case feature [dat]. Given standard minimalist assumptions, this feature will get a 'free ride' by AP-to-Q (which is arguably an instantiation of N-to-D raising). This guarantees that QP now carries [dat] in its set of features as desired. Turning to (16b), [dat] is overtly encoded in D. FF(NP) are attracted by D in standard fashion. Assume now that instead of governing dative Case, $\mathrm{P}$ has a $\mathrm{D}$-feature which attracts $\mathrm{FF}(\mathrm{DP})$. The feature [dat] being encoded in the head of DP will get a free 
ride to $\mathrm{P}$ and thus appear on top of PP. Obviously $\mathrm{Q}$ can appear in different numerations, either with an $\mathrm{N}$-feature as in (14a) or with a partitive feature which is satisfied by a von-PP as in (16b). If FF(PP) are attracted by the partitive feature inherent in $\mathrm{Q}$, it is guaranteed that [dat] appears on top of QP. This explains why not only (15a) is grammatical but also $(15 b) .^{3}$

Notice here an apparent complication which also rests on observations in Gallmann (1997): Non-inflecting nominals of the sort described above can very naturally be used as complements of dative-assigning prepositions:

a. Das ist mit genug / nichts / viel / allerlei / etwas / wenig this is with enough / nothing / much / a lot / something / little vergleichbar comparable

b. Otto ist mit genug / nichts / viel / allerlei / etwas / wenig Otto is with enough / nothing / much / a lot / something / little zufrieden content

A problem for the presently envisaged account would emerge from the standard analysis of GB-theory according to which verbs and preposition are alike in their Case-assigning behavior. Notice, however, that the complement of $P$ may also be a caseless form. PPs like daran, dabei, dahinter, darin, damit as well as their whcounterparts woran, wobei, wohinter, worin, womit all involve prepositions which are normally taken to be assigners of dative Case. However, being adverbial in nature neither $d a$ nor wo should be able to receive Case. If, however, Case inflections and (the functional features of) prepositions are both manifestations of the more abstract notion 'Kase', as among others Suñer (1984) and Grosu (1994) have argued, there is a solution of this problem. That the dividing line between preposition and Case might not be universally justified is easily seen in head-final languages with postpositions and clitic like Case particles such as Japanese where Case particles are usually seen as adpositions. ${ }^{4}$ Assume now that in German the universal notion Kase can be realized as inflectional Case or as a preposition. ${ }^{5}$ We can then

\footnotetext{
3 It also explains, of course, why PPs which involve a DP with another Case do not succeed in QPs which require dative Case, while they do in QPs which require nominative or accusative. The examples are lexically adjusted in order to avoid semantic awkwardness:

(i) *Otto hat viel gegen dies-en Unsinn widersprochen

Otto has [much against this-ACC nonsense]-DAT objected

(ii) Nichts gegen dies-en Unsinn wurde vernommen

[nothing against this-ACC nonsense]-NOM was heard

(iii) Otto hat nichts gegen dies-en Unsinn vernommen

Otto has [nothing against this-ACC nonsense]-ACC heard

4 Cf. Gunji (1995) for Japanese as well as Bittner and Hale (1996) for various other languages.

5 This 'or' is of course inclusive: PPs like bei der Kirche ('near the church-DAT') show that although $P$ may suffice to realize Kase, its DP-complement is still Case marked. Thus $\mathbf{P}$ and morphological Case are not in complementary distribution. Thanks to Denis Bouchard for discussion of this aspect. This
} 
say that the formal features of the complement of $\mathrm{P}$ are attracted to $\mathrm{P}$ which has a Dfeature that needs to be checked. In spite of the unifying notion Kase, P and Case are still different parts of speech with their own rights and restrictions. For Case assignment we assume that $P$ has a Case feature that is checked by the Case of its complement and is subsequently deleted. Assume now that - as in (17) and in the pronominal PPs with $d a-P$ has the same Case feature but no complement which could check it. In this situation, the Case feature inherent in $P$ will survive. This enables us to make precise the intuition that under certain circumstances $P$ may itself be the bearer of oblique Case rather than being the assigner of Case. Under this analysis, the examples in (17) cease to contradict our claim that dative Case must be morphologically realized. ${ }^{6}$

Assume now that the structural Cases nominative and accusative are licensed via appearance in a certain syntactic configuration: The nominative is undoubtedly licensed via agreement with the finiteness feature of the verb; for the accusative we can assume that it is in an agreement relation with a default feature associated with the transitive verb unless otherwise specified. ${ }^{7}$ Overt Case may be present but, as has been shown, is no requirement. Its appearance or absence is regulated by the Elsewhere Condition as already pointed out in note 5 . Oblique Cases like dative, in spite of their relatedness to the verbal projection and in spite of the predictability of the dative, must be morphologically licensed instead. We propose different structures for the two types: (i) Nominals which may project to NP and DP and (ii) Nominals which are in addition headed by the head $\mathrm{K}$ ( $\mathrm{K}$ for Kase). Depending on external conditions, $K$ is realized as oblique Case or as $P$. Case as a functional head $(K)$ has been suggested by Lamontagne and Travis (1987) and by Bittner and Hale (1996). Both stress similarities between the $\mathrm{C}$-system and the $\mathrm{K}$-system with respect to the

situation follows from the Elsewhere Condition (cf. Kiparsky, 1973) which demands the use of the most specific form. Since the set of phrases of type $\left[\mathrm{P} \mathrm{DP}_{\mathrm{DAr}}\right]$ is a proper subset of phrases of type [P DP], the inflected form will be selected as it constitutes the 'special' case. However, there are indications from dialects that dative Case on DP may disappear in the context of P; in (i) and (ii), bet and mit would normally assign dative. Here they don't although dative forms do not seem to be generally unavallable to the speakers. It would be important to know which forms the same speakers use with dative assigning verbs, but we are not aware of any thorough investigation.

(i) Die Fliegen gehen bei die Wurst DUDEN-Grammatik (1984: 367) the flies go to the sausage-NOM/ACC

(ii) Eis mit Früchte Thuringian ice-cream with fruit-NOM/ACC

6 An obvious question in this context is why genitive-assigning prepositions (or postpositions) behave differently, as Schachtl's (1989) example (4a) in the text suggests. We are not sure what the right answer is, but a somewhat radical solution could be that the case assigners in question are not really of the category $P$ because they lack the necessary functional structure. Genitıve-assigning prepositions in German are usually weakly grammaticalized nouns for which genitive on their complement is expected. They tend to assign dative Case once shifted entirely to the category P. This is so for wegen ('because'), (an istatt ('instead of'), trotz ('despite') and perhaps some others. It cannot be an accident that presicely these allow uninflected nouns as complements: wegen Sturm ('because of storm'), (an)statt Peter ('instead of Peter'), trotz Regen ('despite rain').

7 We remain neutral as for the specific implementation; cf. the role of the functional category Agro(bject) in Chomsky (1995) or $\operatorname{Tr}$ (ansitivity) in Collins (1997). 
loss of $\mathrm{C}$ and the loss of $\mathrm{K} .{ }^{8}$ Bittner and Hale propose the structure in (18) where KP is the highest projection of $\mathrm{N}$ in terms of Grimshaw's (1991) theory of extended projections.

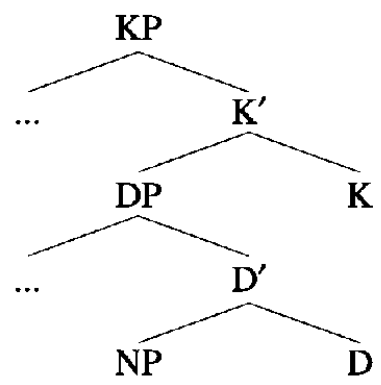

With respect to German we make the assumptions in (19) about K.

(19) a. K stands for the unifying category KASE.

b. K can be realized by a $\mathrm{P}$ which carries the feature [obl] or by the feature [obl] alone.

c. The linear order between $\mathrm{K}$ and $\mathrm{DP}$ follows from principles of morphology. ${ }^{9}$

d. $\mathrm{K}$ must be specified.

(19a) and (19b) say that the feature of oblique Case [obl] or any of its manifestations as [dat] or [gen] may be realized in terms of the functional head $\mathrm{K}$ which may be abstractly identified by overt inflection on DP or by a preposition carrying the feature [obl] in its functional structure. (19c) says that we make no specific claims about order, simply taking for granted what is seen on the surface where synthetic (inflectional) $\mathrm{K}$ is usually suffixal whereas analytic (adpositional) $\mathrm{K}$, namely $\mathrm{P}$, either precedes or follows DP. (19d) says that $K$ must be identified with the required feature [obl]. This requirement obviously follows from the fact that oblique Cases are not structurally licensed in the same way as nominative and accusative are. ${ }^{10}$ Things are obvious where $P$ is inserted deriving KP by virtue of supplying $K$ with the feature [obl]. This situation is not only given in 'insertion' cases such as of-insertion etc. but also where a contentful preposition is found. It should be noticed that the amount of semantic content of P is independent of P's Case feature or Caseassigning property. The interesting cases are here examples such as mit nichts ("with nothing') where nichts lacks a Case paradigm altogether, and where $\mathrm{P}$ is able to

\footnotetext{
8 In Japanese, a complement CP can have an unfilled C-position, and a direct object NP can remain without the particle -o for accusative Case as long as they are in situ, i.e. left-adjacent to the verb. Once they undergo scrambling, $\mathrm{C}$ and $\mathrm{K}$ must be overt; cf. Bittner and Hale (1996: 5) who present data from Saito (1983, 1984).

9 If $\mathrm{K}$ is $\mathrm{P}, \mathrm{P}$ normally precedes $\mathrm{DP}$ in German, although there are a few exceptions; if $\mathrm{K}$ is [dat] it may follow DP in analogy to inflectıonal morphemes or the Case particles seen in other languages.

10 How the latter are exactly licensed exactly is a question that goes beyond the scope of the present article.
} 
make up for this defect. What happens, however, when $\mathrm{K}$ is phonetically empty? In this situation, different technical implementations come to mind as to how $\mathrm{K}$ can be given content, i.e. be supplied with the feature [obl]. One would be that DP, which we assume so far is morphologically endowed with [obl], raises to SpecKP and in doing so supplies $\mathbf{K}$ with the feature [obl] by spec-head agreement. This implementation rests on the Criterion approach which has been argued for by Rizzi (1990) with respect to [wh] and Haegeman and Zanuttini (1991) for [neg]. Under minimalist assumptions there is no need to postulate a specifier for $\mathrm{KP}$, if it is not occupied by a phrase. It is assumed instead that in this case the formal features of DP, FF(DP), raise to $\mathrm{K}$. In this process, [obl] would equally be in the feature structure that heads KP. Any of these mechanisms would guarantee that $\mathrm{K}$ is specified.

Our proposal echoes earlier suggestions in Kayne (1984: ch. 9) and Emonds (1985) that the dative is something like a hidden PP. ${ }^{11}$ Under current assumptions in linguistic theory it is not necessary to state this as Kayne and Emonds did, which is a desirable result because we can now draw a more fine-grained distinction between $\mathrm{P}$-insertion and inflection. P-insertion is but one option. Due to feature movement, there is still the option of identifying $\mathrm{K}$ by virtue of raising the relevant Case feature. The specification of $\mathrm{K}$ is successful as long as there is an overt Case morpheme in the structure that can raise to $\mathrm{K}$ without any violation of locality. The language- and construction-specific differences between adpositional Case and inflectional (oblique) Case reduce in this theory to distinct manifestations of KASE. ${ }^{12}$ We will in the next two sections be concerned with two apparent problems for the proposal we have developed so far. One such problem seems to be set up by proper names, the other by bare plural nouns.

\subsection{Proper names}

Our claim seems to be contradicted by the fact that proper names, which are largely uninflected in modem German, can represent dative Case. As shown in table 2 , proper names add $-s$ for genitive but remain uninflected for the dative. (20) gives some relevant examples:

a. Die Affäre hat Bill Clinton nicht geschadet the affair has Bill Clinton not harmed

b. Amerika hat Afghanistan den Kampf angesagt America has Afghanistan the fight told 'America challenged Afghanistan'

This problem would be difficult to understand without taking a closer look at the historical development of proper names and their representation in the spoken language

\footnotetext{
11 With respect to German see also the discussion in Matzel (1976).

12 Our account of Case in German is also reminiscent of the typology of 'structural deficiency' by Cardinaletti and Starke (1999). NP and DP would be 'deficient' in comparison with KP in that the former rely on mechanisms of syntactic licensing that KP does not.
} 
as well as in dialects. In conformity with the nominal Case inflection of earlier stages of the language, proper names were Case inflected too. Table 3 shows Case inflection in Old High German for the names Hartmuot and Petrus:

Table 3

Case inflection of proper names in Old High German

\begin{tabular}{lll}
\hline NOM & Hartmuot & Petrus \\
GEN & Hartmuot- $e$ s & Petrus- $e s$ \\
DAT & Hartmuot- $e$ & Petrus- $e$ \\
ACC & Hartmuot-an & Petrus-an \\
\hline
\end{tabular}

In later stages, accusative -an or -en was extended to the dative. This inflection was retained deeply into the 19th century and is retained until now in certain dialects. The two examples in (21) are taken from Goethe's Wilhelm Meister $(1820-1829)$, those in (22) are examples of Thuringian dialect which we owe to Peter Suchsland (p.c.):
a. Man sagte Wilhelmen one told Wilhelm-DAT
b. Philinen begegnete auch, daß sie alle Morgen ... also that she every morning ... Philine-DAT encountered man noch schnöder $\begin{array}{ll}\text { Er hat Otton } & \text { gesehen } \\ \text { he has Otto-ACC } & \text { seen }\end{array}$
b. Er ist Otton begegnet he has Otto-DAT met

In most spoken varieties where nominal Case inflection has been lost, person names are used with the definite determiner. Since the determiner retains explicit Case morphology, oblique Case - here usually the dative - is properly represented. In South German and Austrian dialects, the forms in table 4 are the only ones possible, but they are found in many other varieties of colloquial German too.

Table 4

Southern and colloquial forms of Case for proper names

\begin{tabular}{lll}
\hline & Masc. & Fem. \\
\hline NOM & der Otto / der Herr Gruber & die Heidi / die Frau Gruber \\
DAT & dem Otto / dem Hern Gruber & der Heidi / der Frau Gruber \\
ACC & den Otto / den Hern Gruber & de Heidi / die Frau Gruber \\
\hline
\end{tabular}

As has often been pointed out in the literature, the use of the definite article becomes obligatory as soon as the name is modified. This holds for any variety of German:
a. *(die) schöne Helena the beautiful Helena 
$\begin{array}{llll}\text { b. }{ }^{*} \text { (das) } & \text { Bayern meiner Kinderzeit } \\ \text { the } & \text { Bavaria my childhood-GEN }\end{array}$

In the standard language, names of famous females in the performing arts often require the determiner, e.g. *(die) Callas, *(die) Tebaldi, *(die) Schwarzkopf to mention some famous singers. Other proper names show more variation: While names of rivers and mountains are always determined, names of cities are never, and names of countries are only sometimes:
a. Rivers: $\quad *($ der $)$ Rhein, *(die) Donau, *(die) Elbe, *(der) Amazonas, *(der) Ganges
b. Mountains: ${ }^{*}($ die $)$ Zugspitze, ${ }^{*}($ der $)$ Brocken, ${ }^{*}($ das $)$ Matterhorn, ${ }^{*}($ der $)$ Fujiyama
c. Cities: $\quad\left({ }^{*}\right.$ das $)$ Berlin, $\left({ }^{*}\right.$ das $)$ München, $\left({ }^{*}\right.$ das $)$ Dresden, $\left({ }^{*}\right.$ das $)$ Paris
d. Countries: (i) (*das) Deutschland, $\left(*\right.$ das) Italien, $\left({ }^{*}\right.$ das $)$ Schweden, (*das) Ungarn
(ii) *(die) Schweiz, *(die) Mongolei, *(die) Türkei, *(der) Libanon

It is unlikely that in all these cases the overt appearance or non-appearance of the definite article reflects core grammatical principles. ${ }^{13}$ It seems likewise safe to say that the appearance of the definite article cannot be reduced to its standard semantic function because there is no sense in a redundant semantic operation that applies to an entity that is already a 'rigid designator' in the sense of Kripke (1972). Being of category $N(P)$, proper names seem to have the potential of being syntactically selected by $D$. If we assume that also in those cases where no overt determiner appears, a syntactic position for $D$ is nevertheless present, we can make use of Longobardi's (1994) proposal that $\mathrm{N}$ undergoes covert raising to D. Following Wunderlich and Fabri (1996), we may in addition say that the lexicon allows access to inflectional paradigms. Since in German D is connected to a paradigm which provides Case morphology for the dative, we suggest that $\mathrm{N}$ may derive the necessary Case specification after N-to-D raising. We conceive of this process as feature raising by which the formal features of the proper name involve a D-feature which will be checked by raising to $\mathrm{D}$. Since $\mathrm{D}$ has access to a Case paradigm, D, - although silent - can supply oblique Case morphology. If we conceive of this morphology in terms of formal features which must be checked by the functional head $K$, we arrive at the projection KP and N-to-D-to-K raising. This is shown in (25), where the particular word order as well as the label NP are only selected for the sake of demonstration.

13 Paul (1917, vol. II: $160 \mathrm{ff}$.) points out that many German place names derive historically from dative forms (possibly after loss of the locative preposition ze ('zu'; at). 
(25)

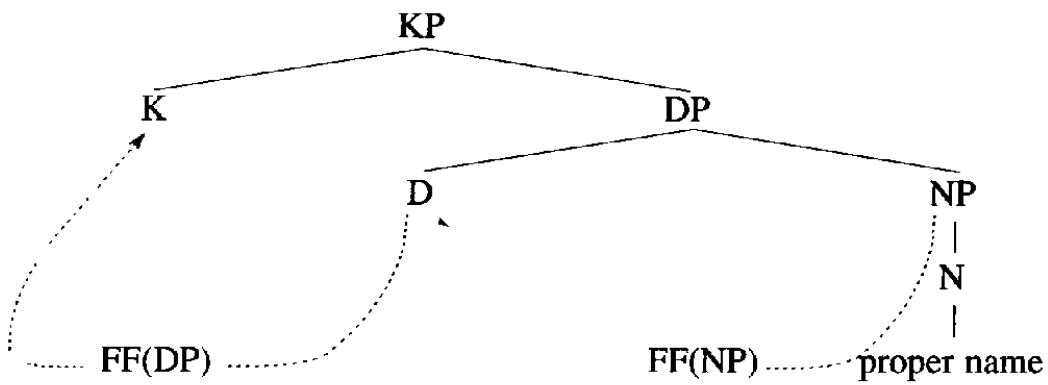

Under the assumption of the pre-minimalist phrase structure in (18), the same result can be achieved, if $\mathrm{N}$ raises covertly to $\mathrm{D}$ where it picks up the required Case specification by virtue of accessing the paradigm of $D$ as suggested above. Then the entire DP raises covertly to SpecKP. Once SpecKP is specified, $\mathrm{K}$ is likewise specified due to spec-head agreement. In each case it is guaranteed that a KP can be projected on the basis of a head $\mathrm{K}$ which is specified for oblique Case morphology. If our assumption of access to paradigms proves to be tenable, this solution offers an explanation of why proper names can derive oblique Case in the absence of visible Case inflection. ${ }^{14}$ Our theoretical proposal of overt oblique Case licensing is expanded in such a way that in the absence of nominal Case inflection access to a relevant paradigm of $\mathrm{D}$ can make up for the deficit. This makes a strong point in favor of the phrase structural implementation of oblique Case which we are suggesting here. Notice that under the present view the dative on a proper noun in Standard German as in $(20 \mathrm{a}, \mathrm{b})$ can only be derived via the presence of an abstract DP and an abstract KP which immediately dominates DP. We will shortly see independent evidence in favor of this phrase structural implementation.

14 One obvious question could be why bare nouns cannot serve as genitives. As a matter of fact, however, proper names have the $-s$ genitive form, as shown in table 2 . Even if $\mathrm{N}$ can be Case-licensed by $\mathrm{N}$ to-D-to-K raising, the Elsewhere Condition would require selection of the more specific form. A more serious problem is that bare substance nouns without any nominal Case inflection such as Hitze ('heat'), Kälte ('coldness') could be expected to derive oblique Case by an analogous process. However, examples in which their Case is not spelled out morphologically are thoroughly ungrammatical:

(i) *Ich kann mich Kälte in Kalkutta kaum erinnern I can REFL coldness in Calcutta hardly remember 'I can hardly think of cold weather in Calcutta"

(ii) *Du darfst diese Pflanzen nicht Kälte aussetzen you must these plants not coldness expose-to

'You must not expose these plants to cold air'

We suspect that these examples are not fully comparablewith proper names because selection of a definite determiner has a semantic effect here and may therefore not exist as a purely formal option. For reasons of space we cannot attempt to discuss these implications here. Uninflected nominals like nichts, viel, genug, allerlei, ervas can never use this strategy because they cannot appear with determiners at all.

(iii) a. *das/ein nichts

b. *das/ein viel

c. *das/ein genug 


\subsection{Bare plurals}

Another potential counterexample to our proposal could be that bare plurals may function as datives but - as was already shown by (2a) - not as genitives. Consider the following contrast:

a. \{Dirigenten / Bauern\} soll man nicht \{widersprechen / schaden\} DAT conductors / farmers should one not object / harm 'One should not \{object to / harm\} (conductors / farmers\}'

b. ${ }^{*}\{$ Dirigenten / Bauern $\}$ kann ich mich leider nicht GEN conductors / farmers can I REFL unfortunately not erinnern remember 'Unfortunately I cannot remember [conductors / farmers \}'

It seems as if the restriction for oblique Case holds only for genitives but not for datives. On the basis of her investigations, this is Schachtl's (1989) conclusion. Schachtl argues for nominative, accusative and dative as a natural class, and many researchers - especially those who take dative to be a structural Case - seem to at least implicitly accept this conclusion. But then the asymmetries reported in section 2.1 through 2.3 are somewhat unexpected.

A look at the history of nominal Case morphology can help to throw light on the issue. The relevant paradigm is the one in which we find total Case syncretism in modern German. Each plural ends in - $(e) n$. Examples are given under the columns for bare plurals in table 2. The predecessor of this class is the Old High German (OHG) $n$-declension which contained nouns of all three genders. As table 5 shows, OHG has the distinct Case affix -o for the genitive plural which is lost in Middle High German (MHG) and New High German (NHG). The example is the neuter herz ('heart').

Table 5

Old, Middle and New High German $n$-declension

\begin{tabular}{llll}
\hline & OHG & MHG & NHG \\
\hline NOM & herz+un (+on) & herz+en & Herz+en \\
GEN & herz+on+o & herz+en & Herz+en \\
DAT & herz+om & herz+en & Herz+en \\
ACC & herz+un (+on) & herz+en & Herz+en \\
\hline
\end{tabular}

The transition from OHG to MGH is characterized by two major phonological processes: (i) loss of genitive $-o$, and (ii) neutralization of place of articulation ([dental] vs. [labial]) in the nasal. While this change results in a loss of genitive marking, it does not result in a loss of dative marking. Although the dative has become nondistinct from the nominative and accusative, its morphological representation 
remains. This explains why bare $-(e) n$ plurals are well-behaved in examples such as (26a) but not in examples such as (26b). Our theory provides exactly the right generalization: Both dative and genitive are oblique Cases which rely on overt morphology in order to project a KP. In bare plurals, the genitive morphology has been lost. Therefore no KP can be projected from them. ${ }^{15}$ The dative morphology has been neutralized but remains as a portmanteau suffix which, however, is nevertheless a trigger for the syntactic projection of KP.

\subsection{Binding}

Binding in German shows an asymmetry that disfavors dative arguments as potentials binders. This restriction pertains, however, only to anaphoric (A-) binding, not to variable ( $\mathrm{A}^{\prime}-$ ) binding. Consider anaphoric binding first. As Vogel and Steinbach (1995) and relevant references given there show, nominative and accusative DPs can bind anaphors but dative DPs cannot: ${ }^{16}$

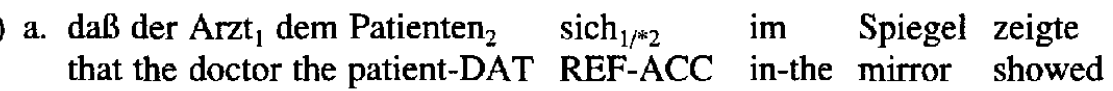

DAT $<$ ACC

that the docter the patient-ACC REF-DAT in-the mirror showed

b. daß der Arzt $_{1}$ den Patienten sich $_{1 / 2}$ im Spiegel zeigte

$\begin{array}{lll}\text { a. Peter hat die Gäste } & \text { einander } & \text { vorgestellt } \\ \text { Peter has the guests-ACC } & \text { each-other-DAT introduced }\end{array}$

15 Presence of a morphological basis is a necessary condition for the projection of KP, but it cannot be considered a sufficient condition. As has been pointed out by Gallmann (1990: 264 f.), examples like (i) and (ii) are ungrammatical although -es is unambiguously a marker of genitive Case:

(i) *Die Verarbeitung Holz-es aus Brasilien

the processing wood-GEN from Brazıl

'the processing of wood from Brazil'

(ii) *Ich erinnerte mich Holz-es aus Brasilien

I remembered REFL wood-GEN from Brazil

'I remembered wood from Brazil'

These examples become grammatical as soon as the bare noun is preceded by an agreeing determiner or adjective. Obviously, the nominal genitive inflectıon has become inactive for the projection of KP. Only the 'Saxon' $-s$ form that appears with proper names seems to retain this ability. For discussion of the various complications cf. Gallmann (1990) and Lindauer (1995).

16 Obviously this is not true in Hungarian as the following example from È. Kiss (1991) shows, although the dative is clearly headed by the particle $-n a k$ :

(i) A lányok-nak megmutattam egymást

the girls-DAT showed-I each-other-ACC

'I showed the girls each other'

We have nothing to say here about languages in which Case is uniformly marked by adposition ('Case particle'), and where the phrase structural difference between KP and DP may be entirely absent.

Our examples in (27b) and in (28a) also lead to the question how the reflexive sich and the reciprocal einander can derive KP although they seem to be morphologically inert and can certainly not be dominated by a DP from which they could derive morphological Case. While we don't have more to say about sich than that it is in a paradigmatic distribution with pronominals which do have a morphological dative, einander is clearly derived from ein- $d$-ander- (one the other), and this form encodes morphological Case as seen in ein-er (NOM) d-en (ACC)/d-em (DAT) ander-en. 


\section{b. *Peter hat den Gästen einander vorgestellt DAT<ACC Peter has the guests-DAT each-other-ACC introduced}

This is all the more surprising as in these examples both objects have argument status, and the unmarked order of constituents DAT $<A C C$ is exactly the one which leads to a failure of A-binding. The only way for one object binding the other, thus, requires scrambling or some other deviation from the canonical IO $<D O$ order. As Steinbach and Vogel also point out, this restriction is absent in variable binding, as shown by the data in (29). The same holds also for negative QPs like keinem Patienten ('no patient-DAT') or Wh-phrases such as welchem Patienten ('which patientDAT'):

$$
\begin{aligned}
& \text { a. daß der Arzt jedem Patienten } \\
& \text { that the doctor each patient-DAT }
\end{aligned}
$$
b. daß der Arzt jeden Patienten 2 seiner 2 Schwester vorstellte that the doctor each patient-ACC his nurse-DAT introduced

DAT $<$ ACC

ACC $<$ DAT

What is the reason for the binding asymmetry that disfavors the indirect (dative) object, and its absence in variable binding? Our account of oblique Case provides a straightforward answer: Since datives are licensed as KPs, K is a head that disallows the referential index on the DP immediately dominated by KP to bind an anaphor to its right. Nominative and accusative arguments are simply DPs. If these c-command an anaphor in their local domain, their referential index can freely bind it. The situation appears to be the same as in PPs:

(30) a. Der Arzt $_{1}$ mußte den Patienten ${ }_{2}$ erst wieder [an $\operatorname{sich}_{1 / 2}$ ] gewöhnen the doctor must the patient again at REF acquaint

$\mathrm{ACC}<\mathrm{PP}$

'The doctor had to get the patient slowly get acquainted with himself again'

b. *Der Arzt mußte [an [den Patienten] $]_{2}$ ] sich $_{2}$ erst wieder gewöhnen

$\mathrm{PP}<\mathrm{ACC}$

Let us make the plausible assumption that Boolean operators such as $\neg, \exists, \forall$ and also [+wh] are based on grammatical features rather than on referential indices, the latter being part of the semantic system (cf. Reinhart, 1987). From this it follows that there is pied-piping of operator features but not of referential indices. Features engage in projection extension (in our implementation, Move-F), thus, passing welldefined barriers of syntactic movement such as DP and - in German and most other languages - PP. The binding facts shown in (31) and (32) indicate that the distinction we are drawing rests on solid independent motivation:

(31) a. *Ben's mother loves himself

b. $\left[\text { Ben }_{1} \text { 's Mutter }\right]_{2}$ liebt sich* ${ }_{1 / 2}$

(Reinhart, 1987: 166) 
(32) a. [No student ${ }_{1}$ 's advisor] has ever given him ${ }_{1}$ any trouble

b. [No student ${ }_{1}$ 's advisor's teaching assistant] has ever given him ${ }_{1}$ any trouble

As one can see in (31), neither English nor German permits anaphoric binding from the specifier of DP, a position which does not c-command the anaphor. Contrary to that, the negation-carrying specifier in (32) can be embedded in DP-specifiers of arbitrary depth and still license variable binding and negative polarity items like ever and any. We take the fact that the distinction between $\mathrm{A}$ - and $\mathrm{A}^{\prime}$-binding carries over to the German dative as evidence for the correctness of the theory proposed so far.

Nevertheless, the mere presence or absence of Case morphology or a preposition cannot be taken as a foolproof prediction for binding relations. In English, the following examples show grammatical binding relations, although the binder is either a 'dative' or part of a PP (cf. Williams, 1994: 220ff.) for more discussion w.r.t. English):

(33) a. I showed John himself $_{1}$ in the mirror

(Barss and Lasnik, 1986)

b. I showed the professors ${ }_{1}$ each other ${ }_{1}$ 's student (Barss and Lasnik, 1986)

c. We talked with Lucie ${ }_{1}$ about herself $f_{1}$

(Reinhart and Reuland, 1993)

d. I talked to the linguists, about each other, 's last book review

As far as corresponding German sentences can be constructed such as *Ich zeigte dem Hans sich im Spiegel and *Ich habe mit Lucie über sich geredet, they are generally unacceptable.

How is this sharp contrast between English and German possible? We believe that the 'dative' in (33a,b) is not headed by KP, the indirect object being licensed in purely configurational terms. It seems unnecessary to repeat the well-known facts about the 'dative' construction in English in the present context. (33c,d) do not constitute a counterexample either because there must be a parse which reanalyzes $\mathrm{V}$ and $\mathrm{P}$ in such a way that PP ceases to be a barrier. Where no possibility of reanalysis exists, binding from PP seems to be hampered. Reinhart and Reuland (1993), Williams (1994) and others mention the deviance of *We talked about Lucie with herself. Whichever proposal is taken, the difference between English and German is likely to reduce to the difference that allows P-stranding and pseudopassives in English but not in German.

Potential counterexamples in German are cases mainly involving reciprocals. In (34a) an antecedent of the reciprocal inside PP seems as possible as the dative antecedent in (34b).

(34) a. Wir haben von den Autoren ${ }_{1}$ [Protestschreiben an einander ${ }_{1}$ ] we have from the authors protest-letters to each-other bekommen received

b. Der Wirt hat den Gästen ${\text { [die Zimmer von einander }{ }_{1} \text { ] }}^{2}$ the inn-keeper has the guests-DAT the rooms of eachother 


\section{gezeigt}

shown

According to Chomsky (1986), however, there are reasons to assume an implicit argument in the complex NP/DP which contains the reciprocal. If this implicit argument is the actual binder, these examples do not constitute an argument against the assumption that anaphors (of this kind) require a strictly c-commanding antecedent, and that neither PP nor KP can guarantee that the referential index of the DP c-commands the anaphor. The idea that a dative antecedent relies on the presence of an implicit argument in the complex DP for the licensing of a reciprocal receives support from the following pair of examples:

(35) a. Ich habe die Leute ${ }_{1}$ über die Kinder von einander
I have the people-ACC about the children of each other
aufgeklärt
informed
b. Ich habe den Leuten ${ }_{1}$ über die Kinder von einander eine
I have the people-DAT about the children of each other a
Nachricht uiberbracht
news conveyed

(35a) is ambiguous. According to one reading, a set of people $\{a, b\}$ was informed about the children of a set of people $\{c, d\}$ and the set $\{c, d\}$ was informed about the children of the set $\{a, b\}$. According to the other reading, there is an implicit argument in DP which binds the reciprocal in such a way that out of a set of people $\{a$, b\}, a was informed about the children begotten with $b$, and $b$ was informed about the children begotten with a, i.e. in this second reading a parental relation between a and $\mathrm{b}$ is implied which is lacking in the first reading. Interestingly, (35b) does not show such an ambiguity. The only reading is the second one, namely the one with an implicit argument in DP that can license the reciprocal. If we are right, this result can be interpreted in favor of a KP for datives which blocks binding of an anaphor. Binding would then rely on the presence of an implicit argument. In examples where this possibility is excluded, datives (as opposed to accusatives) cannot bind reciprocals: ${ }^{17}$
a. Der Student hat die Professoren
über einander ${ }_{\mathfrak{l}}$ aufgeklärt the student has the professors-ACC about each other informed
b. *Der Student hat den Professoren über einander ${ }_{1}$ Witze erzählt the student has the professors-DAT
about each other
jokes told

\footnotetext{
17 As expected, a slight change in word order rescues (36b). In (i) the phrase structure involves, of course, the NP [Witze über einander], something like a picture noun phrase which may contain an implicit argument:
}

(i) Der Student hat den Professoren, Witze über einander ${ }_{1}$ erzählt the student has the professors-DAT jokes about each other told 
Various Romance languages use prepositions as Case particles to mark the direct object. There is reason to believe that these particles do not project a PP. One such reason stems from binding. According to Comorovski (1996: 117), an anaphor can be bound by an object marked for object Case with pe, while such binding is impossible from a true PP. Her examples from Romanian appear in (37): ${ }^{18}$

$$
\begin{aligned}
& \text { a. } \mathrm{L}_{1} \text {-am intîmpinat pe Ion cu o intrebare despre sine }{ }_{1} \\
& \text { him I-have met PRT John with a question about self } \\
& \text { 'I met John with a question about himself' } \\
& \text { b. } \mathrm{M} \text {-am despartit de Ion cu o întrebare despre el }{ }_{1} \\
& \text { myself I-have parted from John with a question about him } \\
& \text { / }^{*} \text { sine } \\
& \text { / himself } \\
& \text { 'I have parted from John with a question about him / himself' }
\end{aligned}
$$

This is one more indication that although the morphological encoding of Case is important and can be decisive, mere focusing on the morphological form would not be sufficient to draw the proper distinctions. There is an exact parallel to the Case paradigm of German. Although the accusative is distinctly and unambiguously marked for the masculine singular (cf. table 1), we have found no reason to assume a projection of KP in this case. We have in addition found the reverse case, namely proper names which appear morphologically unmarked throughout, but can rely on oblique morphology under certain circumstances by accessing the relevant paradigm of determiners.

Before closing this section, let us note that there are questions which we cannot even begin to address in this context. For example, Icelandic dative ('quirky') subjects can bind reflexives (cf. Sigurosson, 1989: 207). It would be necessary to explore in detail whether there are reasons not to postulate a KP for them. Thus, what we had to say about binding cannot be taken as conclusive evidence in favor of our proposal. We hope, however, that the core correspondences between KP and binding restrictions are more than accidental.

\subsection{Secondary predication}

Another interesting datum that is reported by Vogel and Steinbach (1995) concerns the subject of a secondary predicate: According to them, secondary predicates can be linked to a nominative or an accusative but not to a dative. Witness the examples in (38) where we indicate the intended predication by the subscripts $x$ and $y$ :

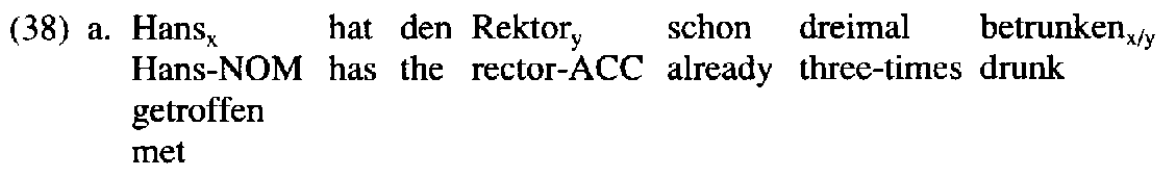

\footnotetext{
18 A problem which Comorovski mentions is, however, that it remains unclear in (37a) whether the anaphor is bound by Ion or by the clitic.
} 


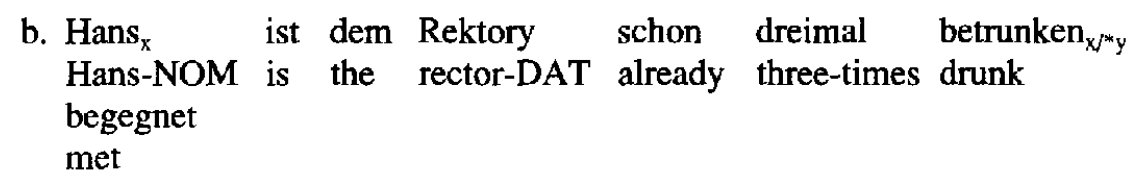

The two examples are semantically close enough to venture the claim that the objectDP does not have a different theta-role in the two cases. It is important to notice that Hans bears in neither case an agent role. The difference is simply that treffen requires an accusative object, while begegnen require a dative object. The latter fails as the subject of the predicate betrunken. The theory developed above seems to offer a natural explanation of this phenomenon: If the dative argument is a KP and not simply a DP, then the head $\mathrm{K}$ could prevent DP from c-commanding the predicate as we have argued w.r.t. binding already in the previous section. Since in our account oblique Cases such as the dative share similarities with PPs, we expect the same restrictions for datives and for DP which are immediately dominated by PP. Williams (1980: 206) proposes a c-command condition on predication which requires that if $\mathrm{NP}$ and a predicate $\mathrm{X}$ are coindexed, then NP must c-command $\mathrm{X}$ or $a$ variable bound to $X$. The contrast between (39a) and (39b) which is taken from Williams (1994) demonstrates what happens when c-command fails: ${ }^{19}$

(39) a. John ate the meat raw

b. *John ate at the meat raw

Nevertheless, the situation is not as straightforward as these few observations might suggest. Williams (1980) observes that the indirect object (i.e. the 'dative') Bill in the example John gave Bill the dog dead fails to connect with the predicate dead, although it c-commands it. He proposes a theta-theoretic restriction which could be captured by the thematic hierarchy that has been proposed in Jackendoff (1972: 43ff.) and elsewhere. Certain examples from German also suggest that the thematic hierarchy may be a decisive factor. Especially experiencer datives seem to serve as subjects of secondary predicate rather smoothly, as the acceptability of (40b) demonstrates:

(40) a. Der Obdachlose ist unglücklich, weil ihn auch betrunken the homeless is unhappy because him-ACC also drunk noch friert still freezes

19 Demonte (1987) shows that in Spanish the Case marker $a$ allows the object to license a secondary predicate, while an NP in a 'real' PP does not:

(i) Juan la encontró a Maria borracha

Juan her found to Mara drunk 'Juan found Maria drunk'

(ii) *Juan le habló a Maria borracha Juan her spoke to Mara drunk 'Juan spoke to Maria drunk' 
'The homeless man is unhappy because he even feels cold when drunk'

b. Der Obdachlose ist unglücklich, weil ihm auch betrunken the homeless is unhappy because him-DAT even drunk noch kalt ist still cold is

If experiencers are higher in the hierarchy than themes, the experiencer would in both (40a) and (40b) serve as the external argument of the AP betrunken, irrespectively of its Case. Thus, under the assumption that datives project a KP in every case, we cannot maintain an explanation in purely phrase structural terms. Before such a conclusion is drawn it would be necessary, however, to explore the status of experiencer datives in more detail. We leave this to future research. For the time being, only examples such as those in (40) would address the issue at hand. We leave it at this inconclusive note.

\subsection{Extraction}

Müller (1995) observes that dative as opposed to accusative DPs do not allow extraction:

(41) a. [Über Scrambling] $]_{1}$ habe ich einem Buch über Optionalität about scrambling have I a book-DAT about optionality

[einen Aufsatz $t_{1}$ ] hinzugefügt

an article-ACC added

'I have added to a book about optionality an article about scrambling'

b. *[Über Optionalität $]_{2}$ habe ich einen Aufsatz über Scrambling about optionality have I an article-ACC about scrambling [einem Buch $\mathrm{t}_{2}$ ] hinzugefügt

a book-DAT added

'I have added an article about scrambling to a book about optionality' 20

If $\mathrm{K}$ induces an extra functional layer for dative objects that is absent in accusative objects, the barrier effect is expected. Since in German PPs are extraction islands, the close analogy between datives and $\mathrm{PP}$ is once again highly suggestive.

Notice that extraction from dative DPs is not per se impossible. In cases of wasfür splitting where was leaves a was-für phrase, extraction from dative is fine.

26) One reviewer notices that (41b) may also be ruled out because of crossing $A^{\prime}$-dependencies due to object-scrambling, but also notices that its ungrammaticality remains after the purported problem is taken care of:

(i) *[Über Optionalität $]_{2}$ habe ich [einem Buch $t_{2}$ ] einen Aufsatz über about optionality have I a book-DAT an article-ACC about Scrambling hinzugefungt scrambling aded 
(42) Was, hast du [ $t_{1}$ für einem Buch] einen Aufsatz zugefügt? what have you for a book-DAT an article added 'What (kind of) book did you add an article to?'

But this is no exception to Müller's observation. If was is originally located where the trace appears in (42), it is in the specifier of für and not included in KP in a technical sense, assuming here the idea that specifiers are not properly included in XP because they are not dominated by $\mathrm{X}^{\prime}$ or because they are adjoined and thus form only an outer segment of XP. ${ }^{21}$ Notice that once an element is in SpecPP, extraction from PP is possible in German as well.

(43) a. Peter hat $\mathrm{da}_{1}$ schon lange $\left[\begin{array}{ll}\mathrm{t}_{1} & \text { von }\end{array}\right]$ geträumt Peter has there already long of dreamed 'Peter has dreamed of that since a long time'

b. $\mathrm{Wo}_{1}$ hat Peter schon lange $\left[\mathrm{t}_{1}\right.$ von $]$ geträumt? where has Peter already long of dreamed 'Of what has Peter dreamed since a long time?'

One can also consider extraction from genitive DPs, but since verb-governed genitive is not all too frequent, it is not easy to come up with many examples. Those which could be expected to be plausible candidates, never lead to acceptable results whereas was-für split is again grammatical or at least significantly better. ${ }^{22}$ Thus, our suggestion pertains to oblique Case in general.

(44) a. *[Über Optionalität $]_{1}$ konnte ich mich [keines Buches $t_{1}$ ] entsinnen about optionality could I REFLno book-GEN remember

b. Was, hast du dich [ $t_{1}$ für eines Buches] entsonnen? what have you REFL for a book-GEN remembered

\subsection{Topic drop}

German has a rule of topic drop which applies exclusively to SpecCP and by which a DP can be nullified which refers to an entity that has been talked about in the immediately preceding discourse. Huang (1984: $546 \mathrm{ff}$.) attributes the core observations to Ross (1982). The examples which appear in the set reported in Huang are all such that either a nominative or an accusative DP has been dropped:

21 Den Besten (1989: ch. 5) rejects was-für split in datives, but his examples (e.g. Was hast du für Leuten geholfen? 'What sort of people did you help?') are in our view either perfectly grammatical or can be explained without recourse to the status of the dative.

12 According to Susanne Trissler (p.c.) there are speakers who do not accept was-fur phrases in the genitive at all. This restriction may, however, have a stylistic rather than a syntactic source because wasfür belongs to the informal style of the language from which the genitive has largely disappeared. 
(45) a. Ich hab' ihn schon gesehen

I-NOM have him-ACC already seen

'I saw him already'

b. [ ] hab' ihn schon gesehen

[]$=\mathrm{NOM}$

c. [ ] hab' ich schon gesehen

[]$=\mathrm{ACC}$

Huang refers to an observation by $R$. Janda who suggests that other phrases than noun phrases can be deleted as well. The example that should demonstrate this is reported in (46).

(46) Speaker A: Du mußt dein Bett machen

you must your bed make

'You have to make your bed'

Speaker B: [ ] habe ich schon!

have I already

'I have already'

What could have been dropped here? Obviously the sloppily related VP mein Bett gemacht. In our view this conclusion would be premature though. Notice that this discourse prominent VP can appear in a left-dislocated position and get picked up by the pronoun das:

(47) $\left[_{C P}[\text { Mein Bett gemacht }]_{1}\left[{ }_{C P}[\text { das }]_{1}\left[C^{\prime}\right.\right.\right.$ habe $\left[{ }_{I P}\right.$ ich $t_{1}$ schon $\left.\left.\left.]\right]\right]\right]$ my bed made this have I already

Thus, if the topic to be dropped is a pronominal, it is unnecessary to assume that topic drop can affect other categories than pronominals. In fact there is evidence that topic drop is categorically severely restricted. PPs can, for instance, neither be picked up by das nor can they be dropped. ${ }^{23}$ Predicates like denken ('to think'), interessiert ('interested'), nachdenken ('to reflect (on)'), sich freuen ('to be happy'), sich ärgern ('to be angry'), etc. select PPs which are headed by the prepositions an and über. Thus, PP-drop is not expected to create a problem of recoverability. Nevertheless, the following examples are ungrammatical: ${ }^{24}$

23 Notice that we are not talking about the adverbial $d a$ but about the pronoun das.

24 Some caution is necessary with the choice of the examples. We do not consider here discourses in which the dropped topic corresponds to a verbatim copy in the immediately preceding utterance. This is the case in the following example:

(i) a. Speaker A: Denkst du an unsere Vereinbarung?

think you at our agreement

'Do you think about our agreement?'

b. Speaker B: Ja. [ ] denke ich die ganze Zeit

yes think I the whole time

'Yes, I do all the time'

What we consider here are cases where the dropped topic does not form part of a verbatim repetition. This is especially true for examples without matching Cases as in the following: 
a. *[] denke ich die ganze Zeit think I the whole time

b. *[] hab' ich noch nicht nachgedacht have I yet not reflected-on

$$
[]=[\mathrm{PP} \text { an ...] }]
$$$$
[]=[\mathrm{PP} \text { über ...] }
$$

Exactly the same restriction holds for dative and genitive topics. Although the Case of the dropped topic is fully recoverably from the verb, the following examples are ungrammatical:
a. *[ ] wirde ich nicht
vertrauen
[]$=\mathrm{DAT}$ would I not trust
b. *[] kann ich mich noch gut entsinnen []$=$ GEN can I REFL still well remember

The restricted occurrence of null topics is in all likelihood connected to the fact that oblique Cases have a structural layer, namely the KP, which is absent in nominatives and accusatives, and which produces their similarity with PP. If one considers the null topic as a deficient pronoun in the sense of Cardinaletti and Starke (1999), some interesting parallels with their diagnostics can be observed. As in their cases, there must be an antecedent which is prominent in the discourse, and the deficient - here zero - form is only found in a special position. One core fact about German topic drop is that it is never possible in any other position than in SpecCP. ${ }^{25}$ Cardinaletti and Starke argue that a deficient pronoun is "morphologically lighter than strong pronouns because it contains less (underlying) morphemes, [...] and it contains less morphemes because it realizes less syntactic heads [...]" (1999: 178). If oblique Case is implemented in a KP-shell as we are arguing here, deficient pronouns and null topics cannot represent oblique Case. ${ }^{26}$ The observed distribution makes sense in a syntactic framework in which structural Case is licensed via the Case-checking algorithm of the Minimalist Program in whose original conception (Chomsky, 1993) the structural Cases for (nominative) subject and (accusative) object are checked in SpecAgrsP and SpecAgroP respectively. Under the split-INFL approach to functional verbal categories and I-to-C movement we expect that a designated

(ii) a. Speaker A: Du, der Karl-Heinz will uns besuchen you the Karl-Heinz-NOM wants us visit 'Listen! Karl-Heinz wants to visit us'
b. Speaker B: [ ] kenn' ich nicht
[ACC] know I not
'I don't know [him]'

25 For instance, as pointed out by Huang (1984), both versions of (46a) given in (i) and (ii) where the drop occurs inside IP are ungrammatical:

(i) *Die trage [ ] schon

(ii) *Ich trage [ ] schon

36 We cannot take responsibility for the correctness of this claim in the wide range of pronouns and clitics that are considered by Cardinalett and Starke. For discussion see some of the comments on Cardinalett and Starke (1999) and their reply in van Riemsdijk (1999: 235-290). 
topic position in SpecCP is identifiable via the features of Agrs and Agro. The exact realization of such identification is beyond the focus of the present article, but seems to be close to Emonds' $(1987,1999)$ Principle of Alternative Realization (AR) and Invisible Category Principle (ICP). These principles roughly suggest that a node may remain empty, if its sister is a functional category which shares its feature(s). ${ }^{27}$ Thus, in a sense a position may remain empty where its content is functionally realized 'slightly out of place'. Translated into the checking procedure of the Minimalist Program, this amounts to saying that the Agr-features related to structural Case remain undeleted until I-to-C movement, and that a topic feature is associated with $\mathrm{C}$ which allows SpecCP to remain empty. Important in the present context is the fact that null topics are obviously related to the verbal agreement system, and that oblique Cases pattern in this respect with PPs in being excluded from the mechanism of formal identification in SpecCP. We take this to be another piece of strong support for our syntactic account of oblique Case.

\subsection{Synthetic compounds}

Let us finally consider synthetic (or verbal) compounds, in German grammar 'Rektionskomposita'. Synthetic compounds differ from root compounds by the fact that the non-head is an internal argument of the head. Synthetic compounds would be winedrinking or perhaps also winedrinker; they are interpreted as 'drinking of wine' and 'someone who drinks wine' respectively (cf. Roeper and Siegel, 1978; Selkirk, 1982; di Sciullo and Williams, 1987; Grimshaw, 1990; among others, and see Olsen, 1986; for German). De Bleser and Bayer (1985) observe that in German the direct 'accusative' object may readily be integrated into such a compound, while a 'dative' object may not. Consider the contrast between the b-sentences of (50) and (51):
a. Die Studentin betreut die Kinder regelmäßig the student looks-after the children-ACC regularly
b. Mit Kinderbetreuen verdient man wenig with child-care earns one little
a. Das Rote Kreuz hilft vielen Kindern the red cross helps many children-DAT
b. *Mit Kindernhelfen erlangt man selten Ruhm with child-help attains one rarely honor

Grimshaw (1990: 14f.) attributes similar observations in English to thematic restrictions. Her core examples are the following to which we add their German counterparts:
a. Gift-giving to children
(das Geschenkegeben an Kinder)
b. *Child-giving of gifts
(*das Kinderngeben von Geschenken)

27 For technical details and discussion w.r.t. clitics Emonds (1999: 312-318) should be consulted. 
(53) a. Flower-arranging in vases

(das Blumenarrangieren in Vasen)

b. *Vase-arranging of flowers (*das Vasenarrangieren von Blumen)

But what is incorporated into the compound in the deviant cases is either not the direct argument, or it is a non-argument as in (53b) which corresponds to a PP. Clearly, PPs like any other phrases cannot incorporate into synthetic compounds at all. The following deviant examples can be reduced to either the Head Movement Constraint (under a derivational theory) or an equivalent X-bar principle that blocks non-structure-preserving projections (under a representational theory):

(54) a. Otto fährt nach Berlin

Otto drives to Berlin

b. *Ottos Nach-Berlin-fahren

Otto's to-Berlin-driving

c. *Otto ist ein Nach-Berlin-fahrer

Otto is a to-Berlin-driver

(55) a. Otto liest Romane von Handke

Otto reads novels by Handke

b. *Ottos Romane-von-Handke-lesen

Otto's novels-by-Handke-reading

c. *Otto ist ein Romane-von-Handke-leser

Otto is a novels-by-Handke-reader

If in analogy to PPs, KPs are necessarily phrases, we can account for the deviant example in $(51 \mathrm{~b})$ without recourse to thematic structure. In fact, the majority of simplex dative verbs cannot incorporate their dative object in synthetic compounds, as shown in (56). In (57), we list a handful of apparent counterexamples: ${ }^{28}$

(56) a. *das Dirigentenapplaudieren the conductor-applauding

b. *das Dirigentenausweichen the conductor-avoiding

c. *das Dirigentenbeispringen the conductor-assisting

d. *das Dirigentengrollen the conductor-grudging
a. Arzthelferin
doctor-helper
'doctor's assistant'
b. Gemeindevorstand
community-leader 'parish council'
c. Sponsorendank
sponsor-thank
'thank to a sponsor'

At closer inspection, the examples in (57) turn out to be irrelevant despite the fact that their verbal bases helfen, vorstehen, and danken require dative Case. In each

28 Thanks to Peter Suchsland, Ralf Vogel and Dieter Wunderlich for discussion of this material. 
case an alternative analysis as root compound exists: Helferin beim Arzt ('assistant at the doctor's'), Vorstand der Gemeinde ('head of the community'), Dank an die Sponsoren ('thanks to the sponsors'). In none of these cases is it necessary to assume a direct-object relation of the purported dative argument. As then expected, the choice of gerunds as in (56) reveals that none of these examples succeeds in the demonstration that the dative argument could be incorporated:
a. *Das Arzthelfen ist anstrengend the doctor-helping is strenuous
b. *Das Gemeindevorstehen macht großen Spaß the community-leading makes big fun
c. *Das Sponsorendanken ist eine gehaßte Pflicht the sponsor-thanking is a hated duty

If dative objects cannot be bare nouns as suggested by the KP-analysis, their failure in synthetic compounds is predicted without recourse to semantic or thematic structure. The German data considered here suggest that the KP-analysis amounts to both the simplest and the most successful generalization.

\subsection{A comparative Germanic note}

The bulk of the previous discussion has been about German data. We have seen that German retains the dative in spite of its partial loss of morphological Case, and we have argued that under certain circumstances the necessary morphological Case signature can be derived by access to a paradigm containing the required form. It is, of course, highly interesting to see how oblique Cases are represented in related Germanic languages in which overt Case morphology has been lost or is only present in residual form. Dutch and English are morphologically quite similar in distinguishing nominative and a single object Case in the pronominal system (hij/he versus hem/him). A distinctive form for the dative cannot be recognized. In this situation we expect under the present assumptions about Case licensing substitution of the lost Case morphology by analytic forms. This is clearly true for Dutch and English where overall the loss of the dative can be made up by prepositions. This does not by any means imply that dative and $P$ are in free variation. It has often been noticed that the dative cannot formally alternate with $P$ as notorious pairs like in (59) from $R$. Kirsner and (60) from G. Lakoff and M. Johnson show which we quote from Davidse (1996: 312f.):

(59) a. Irene poured John a drink

b. Irene poured a drink for John

(60) a. I taught Harry Greek

b. I taught Greek to Harry

It is observed that (59a) and (60a) involve the bearer of dative Case more directly in the event than $(59 \mathrm{~b})$ and $(610 \mathrm{~b})$ the referent of the prepositional object. We would 
attribute this effect to the fact that for and to like most prepositions are not fully grammaticalized as Case licensers in the sense of $\mathrm{KP}$ but continue to bear autonomous semantic content which becomes effective in semantic composition. Similar observations can be made in Dutch. Here is an example from van Belle and van Langendonck (1996: 239):
a. Vader bood oma zijn arm aan father offered gran his arm PRT
b. Vader bood zijn arm aan oma aan
father offered his arm to gran PRT

The PP in (61b) induces a transfer reading which leads to the interpretation that gran is offered father's cut-off arm. Similar examples arise in German as shown in Matzel (1976). In comparison with Dutch, Afrikaans seems to be a language where prepositions have made more progress in turning into purely grammatical morphemes. On these grounds de Stadler (1996) defends the view that there is indeed something like a dative shift alternation. In all these languages we see a more or less strong tendency to license Case-less NPs in the function of indirect objects (IO) in a certain position. The most widely known fact in this domain is certainly that the IO in modern English must be adjacent to the verb, that it can undergo NP-movement under passivization but tends to be awkward for many speakers under wh-movement, topicalization etc.:

(62) a. Mary paid John the money

b. John was paid the money

c. ?*Who did Mary pay the money?

d. ?*John, Mary should not pay the money

Standard Dutch is different in not allowing IO-passivization, and the IO can be moved to an $A^{\prime}$-position with or without a supporting preposition (where the use of a preposition is semantically viable), but speakers concede that there is a preference of PP over IO, which we indicate here with $\%:{ }^{29}$
a. Jan toonde hun een foto van Marie Jan showed them a picture of Marie
b. *Zij werden een foto van Marie getoond they were a picture of Marie shown
c. \%(Aan) wie heeft Jan een foto van Marie getoond? at who has Jan a picture of Marie shown

\footnotetext{
29 Henk van Riemsdijk (p.c.). Den Besten (1989: 190) mentions northem Dutch dialects in which the IO undergoes passive as in English. According to László Molnárfi (p.c.), spoken Dutch offers many examples of IO-to-nominative passivization like in Hij werd de deur opengedaan (' $\mathrm{He}_{\mathrm{NOM}}$ became the door opened').
} 
d. \%(Aan) hun heeft Jan een foto van Marie getoond?
at them has Jan a picture of Marie shown

Afrikaans seems to have gone a longer way in the direction of English. According to de Stadler (1996) there is still a resistance against DO-passivization, but certain classes of verbs allow it. Some examples appear in (64).
a. Hy word sy rykdom gegun
he is his wealth allowed
b. Sy word haar voorregte ontneem
she is her privileges taken-away-from
c. Die deur word nog'n lag verf gegee
the door is another coat paint given

It is formally unclear whether die deur in (64c) is the surface subject or the IO, however the pronouns $h y$ and $s y$ in $(64 \mathrm{a}, \mathrm{b})$ are clearly nominatives. According to László Molnárfi (p.c.), such passivization depends on the verb and the degree of 'semantic incorporation' of the DO into the verb. Unlike most English dialects, Afrikaans still allows IO-topicalization and IO-wh-movement, but the unmarked case would be to support the IO with the preposition vir (lexically 'for') which has already taken on many properties of a Case-marker (cf. Molnárfi, 1997). Abstracting away from varying degrees of grammaticalization of prepositions which are likely to play a role, the possibilities and restrictions are the same as in the English cases seen in $(62 \mathrm{c}, \mathrm{d})$.

The ancestors of these languages had oblique Cases and certain verbs which selected these for their objects. Since the morphological Case difference between accusative and dative has been lost, objects are more or less treated uniformly as DO. This is reflected by the fact that datives of earlier stages of the language behave now like accusative objects under passive. For Dutch van Belle and van Langendonck (1996) mention gehoorzamen ('obey'), toelachen ('smile at'), toejuichen ('applaud'), voorbijgaan ('by-pass'), weerstaan ('resist') and volgen ('follow'). Although some of these allow prepositional objects as in aan ... gehoorzamen / toejuichen, they usually show function-changing passives:
a. Ouders worden gehoorzaamd (door kinderen) parents are obeyed by children
b. Het orkest werd toegejuicht (door het publiek) the orchestra was applauded by the audience

The same is certainly true for English and for Afrikaans. Nevertheless, Dutch retains traces of the dative even in mono-transitive constructions. According to Everaert (1982), gehoorzamen may also retain object Case under passivization, which is most readily explained, if the object - haar in (66) - retains dative Case:

(66) Er wordt haar gehoorzaamd there is her-DAT obeyed 
If oblique Cases project a KP, as we have argued so far, it is expected that the system has to make up for the morphological loss which would also trigger the loss of the KP-shell. Under the plausible view that the syntactic structure of language does not undergo rapid changes, we expect on the other hand a certain conservativity in the syntactic changes that follow morpho-phonological changes. It is thus both understandable that double subcategorizations as for Dutch gehoorzamen may persist, and that former oblique Cases are reanalyzed as accusatives (or rather DOCases). The example in (67b) which has been brought to our attention by Maurice Vliegen (p.c.) deviates from the standard expression in (67a) as if the dative mij has been subject to function changing:
a. Deze schoenen passen mij niet meer these schoes-NOM fit me-DAT no longer
b. Ik pas deze schoenen niet meer
I-NOM fit these shoes-? no longer

But this cannot be the explanation because deze schoenen is neither agentive nor does it appear in a door ('by') phrase. What we have here should rather be considered a case of confusion due to the lack of distinct morphology. While a German translation of (67a) would retain the unambiguous dative form mir, Dutch must rely on the ambiguous form $m i j$ (or the clitic $m e$ ). Thus, the two inner objects of an unaccusative verb like passen can easily be confused.

Nevertheless, Dutch and even Afrikaans show sustained stability of the dative in double object constructions. In the Dutch standard language, the IO still refuses to promote to subject, while this is not the case in (the standard language of) English. How should this be possible, if lack of oblique morphology has a direct correspondence with the projection of KP? We cannot hope to present here a satisfactory discussion of this question, but we can at least point to an important difference between West-Germanic OV and English VO: In English, the order of constituents in the double object construction is V-IO-DO, while it is IO-DO-V in West-Germanic. Adjacency between V and IO in English is likely to have created a context of structural licensing of the IO which allows it to become structurally 'deficient' in the sense of Cardinaletti and Starke (1999), whereas the non-adjacency between IO and $\mathrm{V}$ in the latter system is likely to have prevented IO from abandoning its autonomous functional projection. ${ }^{30}$ In English the situation is quite clear: There is positional licensing of the $\mathrm{IO}$ as long as IO is adjacent to the verb. In that case one may say that the IO is formally treated like the DO which is otherwise adjacent to V. Deviations from this licensing have to be met with the projection of a functional shell. Since there is no oblique Case in English, a PP must be projected. Since prepositions are not purely functional but always carry at least residues of semantic content, the projection of PP is expected to yield semantic effects which may be absent in the dative construction. Due to the retention of OV-order, the situation in West Germanic

30 Assume for concreteness that $\mathrm{IO}$ is adjoined to AgroP, and that there are other reasons than Case checking for an XP to move out of VP. 
predicts retention of KP in the face of lost oblique morphology because as long as adjacency between $\mathrm{IO}$ and $\mathrm{V}$ is broken by the intervening $\mathrm{DO}$, there seems to be no way of formally reanalyzing IO as DO. While this may hold for the core cases reviewed above, it remains unclear how Afrikaans and certain varieties of spoken Dutch which we mentioned above can nevertheless break out of this frame and go the way of English in allowing IO-passivization. If we ignore these complications the treatment of which would go far beyond the scope of this article, our predictions square with the facts of Dutch and English rather well. If Dutch retains a KP for IOdatives while English does not, Dutch should pattern with German rather than with English, although it patterns with English in simplex transitive constructions which rest on former dative assigning verbs.

For various reasons not all the tests can be performed, but we may consider binding, secondary predication and extraction. ${ }^{31}$ We present always pairs of Dutch and English examples. $\left({ }^{*}\right)$ indicates that the judgements are not uniform:
a. (*)Ik toonde Jan zichzelf in de spiegel I showed Jan-DAT himself-ACC in the mirror
b. $\left({ }^{*}\right)$ lk toonde Jan en Marie elkaars fotos
I showed Jan and Marie-DAT each-other's pictures-ACC
c. dat Jan deze actrice een foto van haarzelf niet graag toont that Jan this actress a picture of herself not gladly shows
d. I showed John himself in the mirror
e. I showed John and Mary each other's pictures

We see that the Dutch examples in $(68 \mathrm{a}, \mathrm{b})$ pattern with German for some speakers, i.e. the dative cannot bind an anaphor, but that the sentences are accepted by other speakers. The situation in English is different. Both the reflexive and the reciprocal seen in $(68 \mathrm{c}, \mathrm{d})$ respectively can always be bound by the IO. The Dutch case in $(68 \mathrm{c})$ which has been taken from Neeleman (1994) is not an exception, if our earlier explanation can be maintained that the DP may contain an implicit argument that counts as the primary licenser of the zelf-anaphor. Consider next secondary predication.

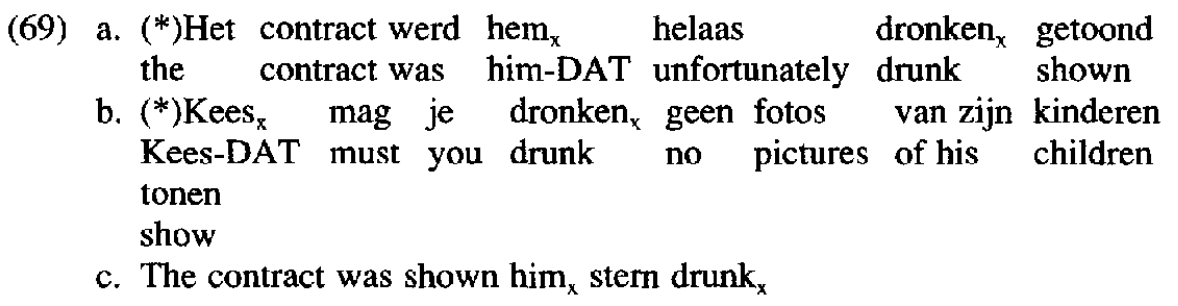

The IO does not easily license a secondary predicate in Dutch for all speakers as shown by the variable judgements on $(69 a, b)$. $(69 b)$ seems to be more fortunate than

31 Thanks to Frans Hinskens and Jan-Wouter Zwart for their judgements of the Dutch data. 
(69a), which might be due to a general preference of subject-orientedness. The English example in $(69 \mathrm{c})$ seems to be perfectly acceptable. Consider next extraction.
a. *Uit Hengelo ${ }_{1}$ heb ik nog nooit [iemand $\left.t_{1}\right]$ cocaïne from Hengelo have I yet never someone-DAT cocaine weggenomen away-taken 'I never took away cocaine from someone from Hengeloo'
b. $\left({ }^{*}\right)$ Uit Hengelo ${ }_{1}$ heb ik nog nooit [iemand $t_{1}$ ] ontmoet from Hengelo have I yet never someone-ACC met 'I never met someone from Hengelo'
c. ? From Oregon ${ }_{1} I$ have never borrowed [any person $t_{1}$ ] any money

(70a) shows the expected restriction, if iemand ... as an IO projects a KP due to its syntactic status as an IO. (70b) shows that in a similar construction extraction from DO is more likely, but that there may be a general problem with extraction from NP, a problem which is, of course, independent of the restriction on oblique Cases we are interested in here. Why should (70c) be deviant? We think this has again an independent reason. There is evidence that extraction (from an object position) is best when the extraction site is a potential focus position. Given English nuclear stress, this is not the case in (70c), i.e. the dative remains automatically outside the focus. This may be the reason why $(70 \mathrm{c})$ is deviant despite the fact that the IO is otherwise licensed like a DO.

The judgements are rather clear in English, but rather variable in Dutch. We think this is exactly what one should expect from the stage of development in which these languages are: English has lost the dative for good and with it the restrictions that set it apart from the accusative. Where it is realized without a supporting preposition, it is confined to a syntactically frozen object position. Dutch, on the other hand, shows variability which can be expected from the syntactic representation of the IO in terms of a KP. The important difference between the KP in German and the Dutch version of KP is, however, that the latter has lost its morphological grounding. The sensitivity for dative Case has clearly disappeared as shown by the behavior of verbs which formerly assigned dative Case and which have now joined the single class of transitive verbs. The sensitivity for dative Case that has survived so far must be built on the necessity of distinguishing the two objects in ditransitives.

\subsection{Summary}

We have started this investigation with the observation that in German oblique Cases require morphological licensing. Case morphology may, of course, also appear on the structural Cases nominative and accusative, but it is not required there, a fact that can be traced back a long way in history. Nominal categories which are necessarily without"morphological Case such as CPs and indefinites like nichts ('nothing') were shown to function as nominatives and accusatives but not as datives (let alone as genitives). We have made the proposal that oblique Case is phrase 
structurally manifested in terms of a functional projection of $K$ (ase) (KP) which comprises not only inflectional but also adpositional Case. The fact that German datives (unlike Dutch and English datives) do not promote to nominative under passivization or undergo other function changing processes can now be explained in terms of a barrier erected by K. Similarly, the observations that datives cannot bind anaphors, cannot freely license secondary predicates, cannot be extracted from, cannot be dropped in topic-drop constructions and cannot incorporate in synthetic compounds can all be reduced to the fact that there is a KP-shell. This shell arguably blocks c-command by the referential index on DP while it allows feature percolation, in analogy to PP. It also prevents the dative object from serving as the subject of a secondary predicate. The extraction facts follow because KP seems to be a barrier in analogy to PP. The restrictions on topic drop show an exact parallel between oblique Cases and PPs. This follows, if features of the verb's extended projection allow the formal identification of zero topics, but not formal features of potential topics which must be licensed by a distinct set of functional projections such as PP and KP. If, thanks to KP, datives are necessarily 'phrasal', they cannot enter word structure. This explains their awkwardness in synthetic compounds.

A comerstone of the account has been that $\mathrm{K}$ is manifested. As we have seen, this holds in full generality for the genitive. The dative, however, seems to show exceptions. In order to retain the theory in its full generality, we had to shift towards a more abstract conception of morphological Case which rests on two processes: Elements which are notoriously deficient in oblique Case such as proper names may raise to positions which are associated with lexical elements that do not suffer from such Case deficiency. Furthermore, the identification of an oblique Case form may require lexical access to the Case paradigm. It could be shown that forms which are morphologically unspecified or underspecified for Case can derive the KP-projection by virtue of analogical structures and paradigms. If true, this is an interesting result about the use of morphology in syntax which shows that Case morphology can under certain conditions be retrieved and activated even if it lacks a phonetic form.

The approach we have taken supports the established view according to which the structural Cases form a natural class which excludes the oblique Cases. Weerman (1996) argued against this view trying to show that it is rather accusative and the 'inherent' Cases which form a natural class and exclude the nominative. Weerman is, of course, aware of the differences between accusatives and datives, but he attributes them to a gradual difference by which inherent Cases contain 'more information' than the accusative. While a serious review of Weerman's arguments would take us too far, we think that the results to be reported below will strongly support our syntactic theory which conforms to the established view but does so on the basis of a novel account of oblique Case. The fact that German permits datives which lack a visible/audible Case specification altogether and datives which show large-scale Case syncretism across the whole paradigm allows us to take a close look at the Case system from a processing perspective. This is the topic of the last section. 


\section{The role of Case in syntactic comprehension}

After having provided an analysis of German Case which relies on a crucial distinction between the 'structural' Cases nominative and accusative and the 'oblique' Cases dative and genitive, we will now proceed to showing which predictions this scenario makes for sentence comprehension. Before we start with a presentation of the relevant intuitive and experimentally elicited data, we want to make explicit what we assume are the central properties of the human sentence processing mechanism (HSPM).

\subsection{Properties of the parser}

The starting point for our excursion into the HSPM is the Garden-Path Theory of Frazier and colleagues (cf. Frazier, 1987; for recent developments, cf. Frazier and Clifton, 1996, and Fodor and Inoue, 1998). The major assumptions of the GardenPath Theory can be summarized as follows: (i) Parsers make immediate decisions about the phrase structure even at the risk of getting the structure wrong, i.e. parsers don't wait. (ii) In the absence of counterevidence, parsers make the most parsimonious structural assumptions about the received input string. (iii) Revisions after reception of disambiguating input can be easy or hard or even totally impossible. In the latter two cases we speak of 'conscious' gardenpaths (GPs). Ideally, GPs predicted by the model should be uncovered experimentally, even if they are spontaneously 'unconscious'.

Property (i) essentially says that there is a pressure on the parser that forces it to make fast decisions. Syntactic decisions have been shown time and again to be of this nature. Bader (1996) and others have shown that even in the processing of verbfinal clauses, as in German embedded clauses, decision making starts way before the verb is received, and that such decision making may lead to very noticeable GP effects. Property (ii) refers to a simplicity metric that is a logical consequence of the infinity of language. As Frazier and Fodor (1978) have put it, there is no alternative to the assumption of the minimal structure compatible with the input at any given moment because, due to the recursive nature of syntax, the complementary assumption would amount to indeterminable and intractable hypotheses about the input. Property (iii) refers to the classical observation that the revision and repair of a misanalysis is cognitively effortful, as measured by prolonged reaction times and gaze durations etc. as well as by distinct electrophysiological brain responses, depending on the experimental methodology. What exactly lies behind error diagnosis, revision or total rejection of the input as ungrammatical is part of a debate that should not centrally concern us here; for discussion see Meng (1998: ch. 7).

\subsection{Overview of processing asymmetries between dative and nominative/accusative Case}

A large body of experimental evidence shows that when the HSPM is faced with a choice between a subject-object (SO) or object-subject (OS) word order, the SO- 
order is usually preferred. A GP therefore results, if a locally ambiguous input has to be changed to object-first order. This finding remains stable across all types of movement investigated so far. In the following examples, ' $i$ ' indicates that German readers are garden-pathed. Note that all garden-path effects that are reported below have been demonstrated experimentally. Some of them can, however, also be experienced intuitively. Observed differences in garden-path strength also rest on statistically reliable experimental results. Below we will abstain from reporting any experimental and statistical details and rather refer the reader to the original experimental work from which the data are drawn.

Consider first the on-line processing of sentences in which the object has been scrambled over the subject, and which - due to a lack of distinct Case morphology are locally ambiguous until the auxiliary verb is received.

(71) a. Er wußte, daß die Sekretärin die Direktorinnen gesucht hat he knew that the secretary the directors searched has 'He knew that the secretary searched for the directors.'

b. ¿Er wußte, daß die Sekretärin die Direktorinnen gesucht haben he knew that the secretary the directors searched have 'He knew that the directors searched for the secretary,'

Number agreement on the finite verb shows that in (71b) the first DP, die Sekretärin, is the object. If the parser has assigned an SO-structure to the partial input string, i.e. [die Sekretärin] [[die Direktorinnen] [gesucht]], reception of plural agreement on the AUX-verb will necessitate a reanalysis giving rise to a garden-path effect (cf. Friederici and Mecklinger, 1996; Bader and Meng, 1999a). Bayer and Marslen-Wilson (1992) could show that in globally ambiguous sentences, SO-order is preferred over OS-order even in contexts where only the latter order would be pragmatically justified. Bader et al. (1999) have extended this finding to locally ambiguous sentences as in (71) by showing that readers are garden-pathed by OS-sentences even in OS-biasing contexts.

The SO-preference seen in sentences as in (71b) as well as in a variety of other subject-object ambiguities follows from the Minimal Chain Principle proposed by de Vincenci (1991) given standard assumptions about clausal structure and movement.

(72) Minimal Chain Principle (MCP)

Avoid postulating unnecessary chain members at $S$-structure, but do not delay required chain members.

Whereas subject-object ambiguities as in (71) have always played a major role for psycholinguistic investigations of German, the distinction between structural Case (nominative/accusative) and oblique Case (dative) has only recently become a focus of psycholinguistic research. Given the hypothesis that oblique Case involves an extra structural layer KP, whereas structural Case does not, we can summarize this research by the claim in (73). 
(73) Due to the presence of KP, the dative should be the least preferred option in situations of syntactic ambiguity. However, once a KP has been erected, it will be costly to undo it again.

In the following, we will argue for the claim in (73) by discussing three processing asymmetries between nominative/accusative Case on the one hand and dative Case on the other. These asymmetries, which are listed below, follow either directly when the GP-theory is applied to the KP-Hypothesis, or they follow in conjunction with a few additional but independently motivated assumptions.

I. First-Pass Parsing I: When a DP has already been identified as an object but its Case is still ambiguous, accusative is preferred to dative Case.

II. First-Pass Parsing II: Dative Case on a relative pronoun is sometime erroneously attracted by the head NP; nominative and accusative Case are not.

III. Second-Pass Parsing: Undoing a KP in second-pass parsing is more costly than inserting a KP, which in turn is more costly than simply changing a Case feature.

\subsection{The case preference principles}

That even such a 'minor' ambiguity as the one between accusative and dative object leads to garden-path effects has been shown by Hopf et al. (1998) in a questionnaire study and in a study measuring event-related potentials. Hopf et al. (1998) investigated the Case ambiguity exhibited by the sentences in (74) in which an indefinite plural noun that is followed by a relative clause is topicalized.

a. Menschen, die in Not sind, sollte man unterstiitzen Humans-ACC who in distress are should one support 'One should support people who are in distress'

b. ¿Menschen, die in Not sind, sollte man helfen Humans-DAT who in distress are should one help 'One should help people who are in distress'

The local ambiguity in (74a) and (74b) is not resolved before the verb is received which requires either accusative or dative Case on the object. Off-line judgements revealed that for various speakers sentences of type (74b) yield a conscious GP. Obviously, the processing of the relative clause adds extra complexity which then reveals the hidden GP effect that can only be uncovered experimentally with less complex material. In an experiment, native speakers of German had to read these sentences frame by frame and decide at the end whether a word presented afterwards had been in the sentence or not. This task was added in order to control for the subjects' attention. The reading process was accompanied by electro-encephalographic recordings which yield wave forms that have become known as EventRelated (Brain) Potentials (ERPs) (cf. the overview in Garrett, 1995, and Brown and Hagoort, 1999). 
In comparison to unambiguous control sentences, the on-line reading of sentences of type (74a) did not exhibit significant differences in the electro-physiological brain responses, but sentences of type (74b) differed from both (74a) and control sentences by showing a prominent centro-posterior negative shift in a time window between 300 and $900 \mathrm{~ms}$ after the dative-requiring verb was presented. This shift - known as $\mathrm{N} 400$ - has been identified as a reliable brain signal of linguistic processing, although mainly with respect to semantic information (cf. Kutas and Hillyard, 1980; 1984). N400 must be seen as a signal of 'surprise' which regularly appears if a builtup expectation is discouraged. The appearance of an $\mathrm{N} 400$ at the point where a Caseambiguous nominal has to be assigned dative Case suggests that, when the parser has a choice between accusative and dative Case, accusative Case is preferred.

Not yet working with the KP-Hypothesis, Hopf et al. (1998) proposed the Case Preference Principle in (75) in order to account for the preference of accusative over dative Case.

\section{Case Preference Principle}

In the absence of morphological or syntactic evidence to the contrary, prefer structural over lexical Case!

However, once a KP-shell for dative objects has been hypothesized, parsing principles peculiar to Case assignment are no longer needed. Given the independently needed Minimal Attachment Principle of the Garden-Path Theory (cf. 76), the dative should be the least preferred option because KP involves an extra layer of structure that is missing in the structural Cases.

\section{(76) Minimal Attachment}

Attach incoming material into the phrase-marker being constructed using the fewest nodes consistent with the well-formedness rules of the language.

In order to test for the generality of the accusative preference found for sentences as in (74), a further experiment investigated sentences with canonical SO-word order where the Case-ambiguous object was located within the so-called middle-field (cf. Bader, 2000). Examples of both locally ambiguous sentences and unambiguous control sentences are given in (77a), where the object DP bears dative case, and (77b), where the object bears accusative case.

(77) a. ¿Der Lehrer hat $\{$ Peters Tante/seiner Tante\} oft widersprochen the teacher has Peter's aunt his aunt often contradicted 'The teacher contradicted Peter's aunt/his aunt often' DAT

b. Der Lehrer hat \{Peters Tante/seine Tante\} oft unterbrochen the teacher has Peter's aunt his aunt often interrupted 'The teacher interrupted Peter's aunt/his aunt often'

ACC

These sentences were investigated using the method of speeded grammaticality judgments. The sentences were displayed word-by-word on a computer screen. At the 
end of the sentence, subjects had to give a grammaticality judgement as fast as possible. The results show a significant decrement of correct judgements and an increase in reaction time for the morphologically ambiguous datives in comparison with unambiguous datives (cf. 77a). Ambiguous accusatives, in contrast, did not differ from unambiguous accusatives (cf. 77b). Unambiguous accusatives and unambiguous datives did not differ from each other either. Thus, even in such simple sentences which normally do not lead to conscious GP effects at all, there is a measurable 'dative effect'.

In sum, experimental evidence shows that, when the HSPM has a choice between accusative and dative Case, accusative Case is the preferred assignment. This follows if, as assumed here, dative objects are phrase-structurally more elaborate than accusative objects.

\subsection{Case attraction}

As pointed out above, research on German sentence parsing has revealed that sentences exhibiting a subject-object ambiguity are usually assigned an SO-structure on first-pass parsing. One major exception to this generalization comes from the phenomenon of 'Case attraction'. Intuitive as well as experimental data show that overt dative Case can be 'attracted' to a head noun from a dative-marked relative pronoun (cf. Meng and Bader, to appear; Bader and Meng, 1999b). ${ }^{32}$ Consider the examples in (78) which involve a proper name in a locally ambiguous embedded sentence that is disambiguated towards an SO-structure by the clause-final verb.

a. daB Eva die ich vorher getroffen habe etwas
that Eva-NOM who-ACC I before met have somthing-ACC
geschickt hat
sent has
'that Eva, who I met just a moment ago, sent something'
b. ¿daB Eva der ich vorher begegnet bin etwas
that Eva-NOM who-DAT I before met have somthing-ACC
geschickt hat
sent has
'that Eva, who I met just a moment ago, sent something'

SO-sentences with or without a die-relative behave more or less alike. In particular, there is no indication that the identification of die as accusative affects the noun Eva in such a way that it will be difficult to integrate the whole NP as the nominative subject. Things change dramatically as soon as a der-relative is attached. Although (78b) is - according to standard assumptions - fully grammatical, it leads to substantial processing difficulties. This suggests that the overt dative inherent in the

32 What we consider here is usually called inverse attraction. This terminology indicates that there are other processes in which attraccion works downwards. Grosu (1994: 110) mentions Classical Greek, Latin, Gothic, Old and Middle High German as well as Modem Romanian as Indo-European languages which exhibit this phenomenon and have partially grammaticalized it. 
feminine relative pronoun der is attracted to the Case-underspecified head noun as shown in (79).

(79) a. Eva [der ${ }_{\text {DAT }}$ ich übrigens letzte Woche begegnet bin]

b. Eva $a_{\text {DAT }}\left[\right.$ der $_{\text {DAT }}$ ich ibrigens letzte Woche begegnet bin]

Once the head noun $E v a$ has been stored as a dative, it will necessarily clash with the clause-final verb which requires it to be a nominative. A GP-effect therefore results in sentences like (78b) although these are truly sentences with the normally preferred SO-word order.

Case attraction occurs even if the head NP/DP is morphologically incompatible with dative Case. For example, Bader and Meng (1999b) have shown that it makes no difference whether the head category is a proper name, as in (78b), or a definite DP like die Frau which is ambiguous between nominative and accusative but incompatible with dative Case. Furthermore, Case attraction also showed up when the head was a masculine DP. Since masculine DPs have a separate morphological form for each of the four Cases of German, they are of particular relevance for demonstrating an asymmetry between structural Cases and dative Case with respect to Case attraction. Two relevant examples are provided in (80).

(80a) is similar to (78b), the only difference being that the sentence starts with the masculine DP der Mann which is unambiguously marked for nominative Case. The immediately following dative relative pronoun is also morphologically unambiguous. In ( $80 \mathrm{~b})$, the syntactic functions of the head DP and the relative pronoun have been exchanged. ( $80 \mathrm{~b}$ ) is a passive sentence where the dative object precedes the subject. ${ }^{33}$ As in (80a), both the head DP and the relative pronoun in (80b) are unambiguous with respect to their Case.

a. ¿daß der Mann dem ich vorher begegnet bin
that the man-NOM who-DAT I before met have
etwas geschickt hat
something-ACC sent has
'that the man, who I met just a moment ago, sent something'
b. daß dem Mann der mir vorher begegnet ist
that the man-DAT who-NOM me before met has
etwas geschickt wurde
something-NOM sent was
'that something was sent to the man, who I met just a moment ago'

Bader and Meng (1999b) have shown that sentences containing the string der Mann, dem (cf. 80a) caused a GP-effect when compared to identical sentences without a relative clause. Sentences containing the string dem Mann, der (cf. 80b), in contrast, did not differ from control sentences without a relative clause. In other words, dative

\footnotetext{
33 Recall from the earlier discussion that in German the dative is not affected by passivization or other function changing processes. A relevant example with morphological Case had been given in (6b).
} 
Case on the relative pronoun can override nominative Case on the head DP, but nominative Case on the relative pronoun cannot override the dative on the head DP.

Partial syntactic representation for the sentences in (80a) and (80b) are given in (81a) and (81b), repectively.

(81) a. [DP der Mann [CP [KP [DPdem $\left.\left.\left.\left.{ }_{\mathrm{DAT}} \ldots ..\right]\right]\right]\right]$

b. [KP $\left[{ }_{D P} \operatorname{dem}_{\mathrm{DAT}}\right.$ Mann [CP [DPder .... ]]]]

(81a) is the configuration where Case attraction is observed. When Case attraction occurs, the projection of the head DP is extended toward KP (cf. 79). (81b) is the configuration where Case attraction does not occur. For Case attraction to occur in (81b) would mean that an already built-up KP would have to be removed from the ongoing phrase-structure representation. Removing existing structure, however, is an operation that the HSPM is reluctant to do (cf. Sturt and Crocker, 1998). The inability of nominative Case replacing dative Case in sentences like (80b) can therefore be traced back to the fact that once the nominative relative pronoun is encountered in ( $81 \mathrm{~b})$, the head DP is already contained within a KPshell which cannot be removed, thereby preventing nominative Case from being attracted.

\subsection{Reanalysis}

We finally turn to processes of second-pass parsing or reanalysis, that is, to the processes that are invoked when the syntactic structure initially assigned to an ambiguous sentence is contradicted by subsequent input. Reanalysis has received much attention in the recent literature on the HSPM (for an overview, cf. Fodor and Ferreira, 1998), the major question being why reanalysis sometimes proceeds without much effort (weak GP-effects) whereas in other instances reanalysis causes major difficulties or is not possible at all (strong GP-effects). With respect to the distinction between structural and oblique Case, the following two generalizations can be made regarding ease of reanalysis.

- Deleting a KP is more costly than inserting one.

- Inserting a KP is more costly than simply changing a Case feature.

The first generalization continues the discussion of the asymmetry between structural and oblique Case seen in Case-attraction phenomena. A relevant example pair is shown in (82) (82a is identical with (78b) discussed above).

a. ¿daß Eva der ich vorher begegnet bin
that Eva-NOM who-DAT I before met have
etwas $\quad$ geschickt hat
something-ACC sent has
'that Eva, who I met just a moment ago, sent something'




b. ¿daß Eva die ich vorher getroffen habe
that Eva-DAT who-ACC I before met have
etwas
something-NOM sent wascht wurde
'that something was sent to Eva, who I met just a moment ago'

These sentences involve a proper name in an embedded active (82a) or passive (82b) construction where, due to the verb-final order, only the last word in the clause, an auxiliary, reveals whether the proper name must be interpreted as nominative or dative. The auxiliary hat confirms a transitive clause with SOV-order in which $\mathrm{S}$ and $\mathrm{O}$ bear nominative and accusative Case respectively. The passive auxiliary wurde, on the other hand, confirms a passivized di-transitive sentence with OSV-order in which $O$ bears dative Case, and $S$, the underlying direct object, nominative Case.

Due to Case attraction, the first NP in (82a) is projected as a KP, an analysis that is disconfirmed upon reception of the auxiliary hat. Repairing the sentence requires the removal of the KP-shell and re-attachment of DP in the phrase marked as the subject. The transition is shown in (83).

(83) a. Eva $a_{\text {DAT }}$ [der ${ }_{\text {DAT }}$ ich übrigens letzte Woche begegnet bin]

b. Eva $_{\text {NOM }}$ [der $_{\text {DAT }}$ ich übrigens letzte Woche begegnet bin]

In $(82 \mathrm{~b})$, the parsing problem is reversed. As already pointed out in the discussion of first-pass parsing preferences in section 3.3, the GP-theory of sentence processing predicts that KP will not be projected unless the parser has evidence to do so. The absence of overt dative morphology in $(82 \mathrm{~b})$ therefore leads to a GP-effect because the input has to be revised in the sense that the phrase structure of the first NP must be extended to KP after the lexicon has been consulted for confirmation that the proper name may qualify as a dative. ${ }^{34}$

Results both from a study using the speeded-grammaticality judgements procedure and from a study where subjects read sentences at their own pace have shown that sentences like ( $82 a$ ) cause a garden-path effect that is much more severe than the one found for sentences like ( $82 \mathrm{~b}$ ) (Meng and Bader, to appear). This finding resembles the asymmetry reported above with respect to Case-attraction: Replacing nominative by dative is relatively easy whereas replacing dative by nominative is relatively difficult. Given that the former revision operation involves the insertion of a KP-shell whereas the latter involves the removal of a KP-shell that has been created on firstpass parsing, this finding follows again from the assumption that in revisions of the input it is in general more difficult to get rid of structure than to insert structure.

With respect to sentence (82b), it is probably not enough to simply insert a KP-shell during reanalysis. Given the tight morphological constraints on dative

\footnotetext{
34 This presupposes information about morphological paradigms in the mental lexicon and lexical access to such paradigms in processing, an assumption that is clearly controversial, but which we cannot discuss here. For the assumption of paradigm information in morphology see Wunderlich and Fabri (1996) and our reference in 2.4.
} 
assignments that have been discussed above, the HSPM has also to make sure that the KP is morphologically licit. Hopf et al. (1998) have therefore proposed that reassignment of dative Case on second-pass parsing obligatorily triggers a process of lexical reaccess which will retrieve the necessary lexical information. This brings us directly to our second point with respect to reanalysis. Lexical reaccess is an additional process hypothesized to occur obligatorily when dative has to be assigned on second-pass parsing, but not when accusative has to be assigned. The reason for this difference is that - as argued above - a KP is in need of an overt or covert morphological license. It is the task of lexical reaccess to verify the existence of such a license before a KP is inserted into the phrasemarker. Assigning accusative, in contrast, is not dependent on a particular morphological license. Furthermore, given the high degree of Case syncretism between nominative and accusative Case, the HSPM might assume that a lexical item is compatible with structural Case in general, as long as it is not marked otherwise (as it is, for example, with masculine determiners). Based on this hypothesis about lexical reaccess, we arrive at the prediction that inserting a KP should be more costly than simply replacing one structural Case feature by another one. A particularly clear instance showing this point is provided by the pair of examples given in (84).

a. ¿Wessen Mutter mother-ACC visited the teacher
whose
'Whose mother did the teacher visit?'
b. ¿Wessen Mutter gratulierte der Lehrer?
whose mother-DAT congratulated the teacher
'Whose mother did the teacher congratulate?'

Both sentences in (84) start with a DP (wessen Mutter) which is completely Caseambiguous. Due to the subject preference in German, this DP will be assigned nominative Case. This assignment must be given up as soon as the second DP is encountered because the second DP is unambiguously nominative marked. In accordance with the Case-assigning properties of the verbs, the initial nominative-assignment to the first DP has to be replaced by the assignment of accusative Case in (84a) and by the assignment of dative Case in (84b). Despite superficial similarity, experimental evidence (cf. Bader et al., 2000) shows that (84a) results in only a modest garden-path effect, whereas the garden-path caused by (84b) is of considerable strength. Bader et al. (2000) have attributed this finding to lexical reaccess being required in (84b) but not in $(84 \mathrm{~b})$.

In sum, our discussion of recovery from GP has shown that when a Case feature has to be replaced by another one during second-pass parsing, the strength of the resulting garden-path effect depends heavily on the syntactic status of the Case features involved. Replacing dative by nominative Case is more difficult than replacing nominative by dative Case. The latter, in turn, is more difficult than replacing nominative by accusative Case. Under the KP-hypothesis, these observations follow, if it is assumed that removing a KP-shell is more difficult than inserting one, and that 
inserting a KP-shell is dependent on processes of lexical reaccess whereas simple replacement of one structural Case feature by another one is not.

\subsection{Summary}

1. Case ambiguity resolution in parsing is not uniform. Research on German has shown that Cases are assigned in accordance with the preference hierarchy NOM $>$ ACC $>$ DAT. The ranking of NOM above ACC follows from the Minimal Chain Principle and is independent of Case theory per se. As we have seen in much detail, these two Cases exist independently of their morphological realization. If dative is syntactically licensed through the functional head $\mathrm{K}$, as we have now argued, the further ranking of ACC above DAT also follows. Dative (and certainly genitive, too) rests on special morphology which is normally visualized as a Case inflection and in abstract syntax as a structural layer associated with it that we called KP. Minimal assumptions by the parser predict that KP will be systematically missed when it is not signaled in the input.

2. Upward attraction of Case is a structure-based operation of the HSPM which seems to apply blindly. However, it is again the attraction of oblique (morphology-dependent) Case which yields effects: Dative-attraction inhibits alternative (and grammatically licit) Case assignments and is able to reverse the usual subject-first preference to an object-first preference.

3. KP influences GP-effects in two directions: A GP results, if due to a lack of overt morphology no KP is projected in first-pass parsing, and if the following verb requires an object which is licensed by KP. A GP also results, if on the basis of attraction, a KP is projected in first-pass parsing but the following verb requires an object which is incompatible with KP.

\section{General summary}

Case in German can be abstract as long as only the 'structural' Cases nominative and accusative are considered. The 'oblique' Cases dative and genitive must be morphologically marked. ${ }^{35}$ While the genitive always requires either a specific inflection or the preposition von ('of'), caseless forms of proper names and certain bare plurals can still function as datives. Closer inspection reveals, however, that nominal categories which lack a Case paradigm altogether systematically fail as representatives of dative Case. On the basis of this, we have argued that oblique Cases have an extra structural layer which is missing in nominatives and accusatives, and which we termed 'Kase phrase' (KP). 'Kase' is a broader notion than inflectional Case because it also comprises prepositions and other adpositions. Uninflected nominals must

35 This should not be confused with the earlier assumption of GB-theory that datives and genitives which are govemed by the vert are necessarily 'lexical'. The arguments in favor of a 'structural', i.e. predictable, dative in double-object constructions are orthogonal to the structural/oblique distinction which we have emphasized in the present article. 
raise to a K-head, if they should be licensed as datives. With the assumption of KP, a number of puzzling asymmetries between dative and nominative/accusative receive a natural explanation: Datives do not take part in function changing operations, they cannot be represented by clausal arguments, they cannot be represented by notoriously uninflected, i.e. particle-like indefinites such as nichts ('nothing'), they cannot serve as binders of anaphors, they do not allow secondary predicates, extraction from them is impossible, and they cannot be integrated in synthetic compounds. All of this follows straightforwardly, if datives but not nominatives and accusatives are headed by $\mathrm{K}$.

In the second part of the article we presented experimental evidence from on-line syntactic processing which tested the predictions of our morphosyntactic account in the context of the GP-theory of human sentence processing. Due to the fact that proper names and $-(e) n$ bare plurals are ambiguous between nominative, dative and accusative, Case-ambiguity resolution could be tested in verb-final clauses. According to the GP-theory, the human sentence processing device pursues only one analysis of the input at a time, and this analysis is the simplest one consistent with the input at any given moment in parsing. As a consequence, object/object ambiguities are always resolved in favor of accusative Case (cf. Hopf et al., 1998; Bader, 2000). Ambiguity resolution in favor of dative has a clear disadvantage which systematically shows up in GP-effects. Since the projection of KP is missed in firstpass parsing, phrase structural reanalysis has to take place. Nothing of this sort is required, if structural Case has to be reassigned. Our theory allows a classical explanation of the 'dative effect' which does not need to resort to independent assumptions about markedness etc. Additional experiments explored the upward attraction of Case from a relative pronoun to an underspecified head noun (cf. Meng and Bader, to appear; Bader and Meng, 1999b). It was found that dative Case is attracted while accusative Case is not (or its attraction does not trigger strong enough effects). The attraction of dative leads to a reversal of the usual subjectbefore-object preference in parsing. What is attracted according to the present theory, is KP. If further input is inconsistent with it, its removal in second-pass parsing is expected to trigger a very noticeable GP effect, which is what we have actually seen.

Syntactic investigations and the investigation of sentence processing were shown to converge straightforwardly on an analysis according to which oblique Cases in German - in particular the dative - rely on a specific functional vocabulary as provided by the inflection morphology of the language.

\section{References}

Bader, M., 1996. Sprachverstehen: Syntax und Prosodie beim Lesen. Opladen: Westdeutscher Verlag.

Bader, M., 2000. The role of memory load in syntactic ambiguity resolution: A reply to Gibson (1998). Ms., University of Jena.

Bader, M. and M. Meng, 1999a. Subject-object ambiguities in German embedded clauses: An acrossthe-board comparison. Journal of Psycholinguistic Research 28, 121-143.

Bader, M. and M. Meng, 1999b. Case attraction phenomena in German. Ms., submitted for publication. 
Bader, M., M. Meng and J. Bayer, 1999. Sentential context effects (or lack thereof) on the processing of subject-object ambiguities in German. Paper presented at the Fifth Conference on Architectures and Mechanisms for Language Processing, University of Edingburgh.

Bader, M., M. Meng and J. Bayer, 2000. Case and reanalysis. Journal of Psycholinguistic Research 29, $37-52$.

Barss, A. and H. Lasnik, 1986. A note on anaphora and double objects. Linguistic Inquiry 17, 347-354.

Bayer, J. and W. Marslen-Wilson, 1992. Configurationality in the light of language comprehension: The order of arguments in German. Ms., University of Vienna and Birkbeck College, London.

van Belle, W. and W. van Langendonck, 1996. The indirect object in Dutch. In: W. van Belle and W. van Langendonck (eds.), The dative, vol.1, 217-250. Amsterdam: Benjamins.

den Besten, H., 1989. Studies in West Germanic Syntax. Doctoral dissertation, Katholieke Universiteit van Brabant, Tilburg. Amsterdam: Rodopi.

Bittner, M. and K. Hale, 1996. The structural determination of Case and agreement. Linguistic Inquiry $27,1-68$.

de Bleser, R. and J. Bayer, 1985. German word formation and aphasia. The Linguistic Review 5, 1-40.

Brown, C. and P. Hagoort (eds.), 1999. The neurocognition of language. Oxford: Oxford University Press.

Cardinaletti, A. and M. Starke, 1999. The typology of structural deficiency. In: H. van Riemsdijk (ed.), Clitics in the languages of Europe, 145-233. Berlin: Mouton de Gruyter.

Chomsky, N., 1986. Knowledge of language: Its nature, origin, and use. New York: Praeger.

Chomsky, N., 1993. A minimalist program for linguistic theory. In: K. Hale and S. J. Keyser (eds.), The view from Building 20: Essays in linguistics in honor of Sylvain Bromberger, 1-52. Cambridge, MA: MIT Press. [reprinted in Chomsky, 1995]

Chomsky, N., 1995. The minimalist program. Cambridge, MA: MTT Press.

Collins, Ch., 1997. Local economy. Cambridge, MA: MIT Press.

Comorovskı, I., 1996. Interrogative phrases and the syntax-semantics interface. Dordrecht: Kluwer.

Czepluch, H., 1996. Kasus im Deutschen und Englischen. Tübingen: Niemeyer.

Davidse, K., 1996. Functional dimensions of the dative in English. In: W. van Belle and W. van Langendonck (eds.), The dative, vol.1, 289-338. Amsterdam: Benjamins.

Demonte, V., 1987. C-command, prepositions and predication. Linguistic Inquiry 18, 147-157.

Di Sciullo, A.M. and E. Williams, 1987. On the definition of word. Cambridge, MA: MIT Press.

DUDEN, 1984. Grammatik der deutschen Gegenwartssprache. Edited by G. Drosdowski. Mannheim: Dudenverlag.

Emonds, J., 1985. A unified theory of syntactic categories. Dordrecht: Foris.

Emonds, J., 1987. The invisible category principle. Linguistic Inquiry 18,613-632.

Emonds, J., 1999. How clitics license null phrases: A theory of the lexical interface. In: H. van Riemsdijk (ed.), Clitics in the languages of Europe, 291-367. Berlin: Mouton de Gruyter.

Everaert, M., 1982. Strutureel passief in het Nederlands. Working Papers in Linguistics 11, 37-74.

Fanselow, G. and S. Felix, 1987. Sprachtheorie: Eine Einführung in die generative Grammatik. Two volumes. Tübingen: Francke.

Fodor, J.D. and F. Ferreira (eds.), 1998. Reanalysis in sentence processing. Dordrecht: Kluwer.

Fodor, J.D., and A. Inoue, 1998. Attach anyway. In: J.D. Fodor and F. Ferreira (eds.), Reanalysis in sentence processing, 101-141. Dordrecht: Kluwer.

Frazier, L., 1987. Sentence processing: A tutonal review. In: M. Coltheart (ed.), Attention and performance XII: The psychology of reading, 559-586. Hove: Erlbaum.

Frazier, L. and C. Clifton, Jr., 1996. Construal. Cambridge, MA: MTT Press.

Frazier, L. and J.D. Fodor, 1978. The sausage machine: A new two-stage parsing model. Cognition 6 , 291-325.

Friederici, A. and A. Mecklinger, 1996. Syntactic parsing as revealed by brain responses: First-pass and second-pass parsing processes. Journal of Psycholinguistic Research 25, 157-176.

Gallmann, P., 1990. Kategoriell komplexe Wortformen: Das Zusammenwirken von Morphologie und Syntax bei der Flexion von Nomen und Adjektiv. Tübingen: Niemeyer.

Gallmann, P., 1996. Die Steuerung der Flexion in der DP. Linguistische Berichte 164, 283-314.

Gallmann, P., 1997. Zur Morphosyntax und Lexik der w-Wörter. Arbeitspapier 107 des SFB 340 Sprachtheoretische Grundlagen für die Computerlınguistik. Stuttgart: Universität Stuttgart. 
Garrett, M., 1995. The structure of language processing: Neuropsychological evidence. In: M. Gazzaniga (ed.), The cognitive neurosciences, 881-899. Cambridge, MA: MIT Press.

Grimshaw, J., 1990. Argument structure. Cambridge, MA: MIT Press.

Grimshaw, J., 1991. Extended projection. Ms., Brandeis University, Waltham, MA.

Grosu, A., 1994. Three studies in locality and case. London: Routledge.

Gunji, T., 1995. Japanese. In: J. Jacobs, A. v. Stechow, W. Sternefeld and T. Vennemann (eds.), Syntax: An international handbook of contemporary research, 99-116. Berlin: Mouton de Gruyter.

Haegeman, L. and R. Zanuttini, 1991. Negative heads and the neg criterion. The Linguistic Review 8, 233-251.

Hopf, J.-M., J. Bayer, M. Bader and M. Meng, 1998. Event-related brain potentials and case information in syntactic ambiguities. Journal of Cognitive Neuroscience 10, 264-280.

Huang. C.-T.J., 1984. On the distribution and reference of empty pronouns. Linguistic Inquiry 15 , 531-574.

Jackendoff, R., 1972. Semantic interpretation in generative grammar. Cambridge, MA: MIT Press.

Kayne, R.S., 1984. Connectedness and binary branching. Dordrecht: Foris.

Kiparsky, P., 1973. 'Elsewhere' in phonology. In: S. Anderson and P. Kiparsky (eds.), A Festschrift for Morris Halle, 93-106. New York: Holt.

É. Kiss, K., 1991. The primacy condition of anaphora and pronominal variable binding. In: J. Koster and E. Reuland (eds.), Long-distance anaphora, 245-262. Cambridge: Cambridge University Press.

Kornfilt, J., 1985. Case marking, agreement, and empty categories in Turkish. Doctoral dissertation, Harvard University.

Kripke, S.A., 1972. Naming and necessity. In: D. Davidson and G. Harman (eds.), The semantics of natural language, 253-355 and 763-769. Cambridge, MA: Harvard University Press.

Kutas, M. and S.A. Hillyard, 1980. Reading senseless sentences: Brain potentials reflect semantic incongruity. Science 207, 203-205.

Kutas, M. and S.A. Hillyard, 1984. Brain potentials during reading reflect word association and semantic expectation. Nature 307, 161-163.

Lamontagne, G. and L. Travis, 1987. The syntax of adjacency. In: M. Crowhurst (ed.), Proceedings of the Sixth West Coast Conference on Formal Linguistics, 173-186. Stanford, CA: CSLI Publications.

Lenerz, J., 1977. Zur Abfolge nominaler Satzglieder im Deutschen. Tübingen: Narr.

Lindauer, T., 1995. Genitivattribute: Eine morphosyntaktische Untersuchung zum deutschen NP/DPSystem. Tübingen: Niemeyer.

Longobardi, G., 1994. Reference and proper names. Linguistic Inquiry 25, 609-666.

Matzel, K., 1976. Dativ und Präpositionalphrase. Sprachwissenschaft 1, 144-186.

Meng, M., 1998. Kognitive Sprachverarbeitung: Rekonstruktıon syntaktischer Strukturen beim Lesen. Wiesbaden: Deutscher Universitätsverlag.

Meng, M. and M. Bader, to appear. Ungrammaticality detection and garden path strength: Evidence for serial parsing. Language and Cognitive Processes.

Molnárfi, L., 1997. Preposisie of kasusmarkeerder? Oor die status van vir in Afrikaans [Preposition or case-marker? About the status of vir in Afrikaans]. Tydskrif vir Geesteswetenskappe 37, 89-106.

Müller, G., 1995. A-bar syntax. Berlin: Mouton de Gruyter.

Neeleman, A., 1994. Scrambling as a D-structure phenomenon. In: N. Corver and H. van Riemsdijk (eds.), Studies on scrambling, 387-429. Berlin: Mouton de Gruyter.

Olsen, S., 1986. Wortbildung im Deutschen. Stuttgart: Kröner.

Paul, H., 1917. Deutsche Grammatik, vol. 2. Halle: Niemeyer.

Plank, F., 1980. Encoding grammatical relations: Acceptable and unacceptable non-distinctness. In: J. Fisiak (ed.), Historical morphology, 289-325. The Hague: Mouton.

Reinhart, T., 1987. Specifier and operator binding. in: E. Reuland and A. ter Meulen (eds.), The representation of (in)definiteness, 130-167. Cambridge, MA: MIT Press.

Reinhart, T. and E. Reuland, 1993. Reflexivity. Linguistic Inquiry 24, 657-720.

Riemsdijk, H, van (ed.), 1999. Clitics in the languages of Europe. Berlin: Mouton de Gruyter.

Rizzi, L., 1990. Relativized minimality. Cambridge, MA: MIT Press.

Roeper, T. and M.E.A. Siegel, 1978. A lexical transformation for verbal compounds. Linguistic Inquiry $9,199-260$. 
Ross, J.R., 1982. Pronoun deleting processes in German. Paper presented at the Annual Meeting of the Linguistic Society of America, San Diego, CA.

Saito, M., 1983. Case and government in Japanese. In: M. Barlow, D.P. Flickinger and M.T. Wescoat (eds.), Proceedings of the Second West Coast Conference on Formal Linguistics, 247-259. Stanford, CA: CSLI Publications.

Saito, M., 1984. On the definition of c-command and government. In: C. Jones and P. Sells (eds.). Proceedings of NELS 14, 402-417. Amherst, MA: GLSA, University of Massachusetts.

Schachtl, S., 1989. Morphological case and abstract case: Evidence from the German genitive construction. In: Ch. Bhatt, E. Löbel and C. Schmidt (eds.), Syntactic phrase structure phenomena, 99-112. Amsterdam: Benjamins.

Selkirk, E., 1982. The syntax of words. Cambridge, MA: MIT Press.

Siguroxsson, H.A., 1989. Verbal syntax and case in Icelandic in a comparative GB approach. Reykjavík:Institute of Linguistics: University of Iceland.

de Stadler, L., 1996. The indirect object in Afrikaans. In: W. van Belle and W. van Langendonck (eds.), The dative, vol. 1, 251-288. Amsterdam: Benjamins.

Steinbach, M., 1998. Middles in German: The syntax and semantics of transitive reflexive sentences. Doctoral dissertation, Humboldt Universitat zu Berlin.

Steinbach, M., 2000. Dative, accusative, and valency reduction. Talk at the 22nd Annual Meeting of the Deutsche Gesellschaft für Sprachwissenschaft, Marburg, 1-3 March 2000.

Stowell, T., 1981. Origins of phrase structure. Doctoral dissertation, MIT.

Sturt, P. and M. Crocker, 1998. Generalized monotonicity. In: J.D. Fodor and F. Ferreira (eds.), Reanalysis in sentence processing, 365-400. Dordrecht: Kluwer.

Suñer, M., 1984. Free relatives and the matching parameter. The Linguistic Review 3(4), 363-387.

de Vincenzi, M., 1991. Syntactic parsing strategies in Italian. Dordrecht: Kluwer.

Vogel, R. and M. Steinbach, 1995. On the (absence of a) base position for dative objects in German. FAS Papers in Linguistics 4.

Weerman, F., 1996. Asymmetries between nominative, accusative and inherent case. In: E. Brandner and G. Ferraresi (eds.), Language change and generative grammar, 95-119. Linguistische Berichte, Sonderheft 7. Opladen: Westdeutscher Verlag.

Wegener, H., 1985. Der Dativ im heutigen Deutsch. Tübingen: Narr.

Williams, E., 1980. Predication. Linguistic Inquiry 11, 203-238.

Williams, E., 1994. Thematic structure in syntax. Cambridge, MA: MIT Press.

Wunderlich, D., 1997. Cause and the structure of verbs. Linguistic Inquiry 28, 27-68.

Wunderlich, D. and R. Fabri, 1996. Minimalist morphology: An approach to inflection. Zeitschrift für Sprachwissenschaft 14, 236-294. 